\title{
MEDIEVAL ENGLISH ALABASTER SCULPTURES: TRADE AND DIFFUSION IN THE ITALIAN PENINSULA ${ }^{1}$
}

\section{ZULEIKA MURAT}

UDC: $7.075(410.1: 450) " 04 / 14 "$ 736.2.033

Preliminary communication

Manuscript received: 23. 01. 2016.

Revised manuscript accepted: 17. 03. 2016.

DOI: 10.1484/J.HAM.5.111359
Z. Murat

Dipartimento dei Beni Culturali: archeologia, storia dell'arte, del cinema e della musica Università degli Studi di Padova Piazza Capitaniato, 7 35139 Padova, Italia

In 1382 Cosmato Gentili, Pope Urban VI's representative in England, got an export license for three large alabaster carvings to be shipped to Rome from the city port of Southampton. This is the first evidence which attests the trade of English alabaster sculptures in Italy. Although only few similar documents survive, the spread of these works of art in Italy is proved by the great amount of existing pieces. Indeed, with more than 40 carvings held in Italy, the Peninsula should be considered among the eagest purchasers of alabasters in Europe. Through a careful investigation of the carvings kept in different Italian regions this essay aims to trace the diffusion of these artworks in the Peninsula. Some unpublished or neglected carvings are here discussed for the first time, and some scattered panels are here recomposed together as part in origin of the same altarpiece.

Keywords: English alabasters; Alabasters in Italy; Santa Croce in Gerusalemme; San Francesco della Vigna; Santa Caterina de' Sacchi; Museo Diocesano di Arte Sacra, Treviso; Museo Diocesano, Vicenza; Pinacoteca del Seminario Vescovile, Rovigo; Museo d'Arte Antica del Castello Sforzesco; Museo Civico di Palazzo Schifanoia; Museo del Tesoro della Cattedrale, Savona; Tommaso degli Obizzi.

On 10 September 1550 the English ambassador in France, Sir John Mason, wrote to the Privy Council from Poissy, saying that 'Three or four ships have lately arrived from England laden with images, which have been sold at Paris, Rouen, and other places, and being eagerly purchased'2.

The ambassador had thus attended one of the most known cases of mass export of artworks in Europe, which took place after the Reformation that banned sacred images from British churches 3 . Among the destroyed and scattered works, there were many alabaster altarpieces, specifically mentioned in the Act of January of 1550 against the 'superstitious books and images' that ordered the destruction of 'any images of stone, timber, alabaster, or earth, graven, carved or painted'4.
Several sculptures entered the European art market. Among the many carvings that reached the Italian peninsula was the 'marble flemish panel with many figures, of four arm'slength wide', which Brother Fabiano, guardian of the church of San Benedetto at Settimo, near Pisa, bought for eight ecus from an English merchant who took it to Italy5. The polyptych - that despite the reference to the Flanders is clearly an English artwork - is now reused as an altar-frontal, and is placed on the church's main altar ${ }^{6}$. Typological and stylistic evidence suggests that the artwork dates back to the mid-fifteenth century ${ }^{7}$, thus implying that the altarpiece was originally exhibited in an English church, from which it was evidently removed after the Reformation. Two other sculptures shared that same fate: the Virgin and Child and the Trinity brought

\footnotetext{
${ }^{1}$ This essay presents the preliminary results of a research I'm conducting at the University of Padua under Prof. Giovanna Valenzano's supervision. The two-year project I'm working on is entitled 'Pale d'altare in alabastro nell'Inghilterra medievale: forme, tipologie, modi di produzione' [Alabaster altarpieces in Medieval England: forms, typologies, ways of production]. I'm grateful to many people who have helped me during the research I have undertaken to write this article: first of all, I am indebted to Luca Mor for all his suggestions and support. I also wish to thank the staff of the many archives, superintendencies, museums and collections I have been visiting in the last months in order to complete this study.

${ }^{2}$ Calendar of State Papers, Foreign Series, of the Reign of Edward VI, 1547-1553 ed. by W. Turnbull, London, 1861, pp. 54-55. W. H. St. J. HOPE, On the Early Working of Alabaster in England, in Illustrated Catalogue of the Exhibition of the English Medieval Alabaster Work held in the Rooms of the Society of Antiquaries, 26th May to 3oth June, 1910, Printed at Oxford for the Society of Antiquaries, Burlington House, London, 1913, pp. 1-15: 13, note 3.

${ }^{3}$ Cfr. E. DUFFY, The Reformation and the Alabastermen, in Object of Devotion. Medieval English Alabaster Sculpture from the Victoria and Albert Museum, ed. by P. Williamson, with contributions by F. Cannan, E. Duffy, S. Perkinson, Alexandria, 2010, pp. 54-65.

${ }^{4}$ Tudor Constitutional Documents 1485-1603, ed. by J. R. Tanner, Cambridge, 1951, p. 113; F. CHEETHAM, English Medieval Alabasters. With a Catalogue of the Collection in the Victoria and Albert Museum, 2nd Ed., Woodbridge, 2005, p. 52.

${ }_{5}^{5}$ The translation provided here is my own. The original document, that reads 'la tavola di marmo fiandresca di braccia 4 lunga con più figure', is held in the Archivio di Stato di Firenze (Corporazioni religiose soppresse, n. 119, c. 66v). See also: M. L. TESTI CRISTIANI, L'arte medievale a Cascina e nel suo territorio, Pisa, 1987, pp. 129-135; EAD., Una tavola di marmo fiandresca... con piu figure, da Nottingham a Settimo di Pisa, in Arte medievale a Pisa tra Oriente e Occidente, Rome, 2005, pp. 513-516. On this artwork see also R. PAPINI, Polittici d'alabastro, in L'Arte, 13, 1910, fasc. I, pp. 202-213: 204-206; W. L. HILDBURGH, Some English medieval alabaster carvings in Italy, in The Antiquaries Journal, 35, 1955, nn. 3-4, pp. 182-186: 182.

${ }^{6}$ In 1803 the altarpiece was reshaped and moved on the front of the altar. The four sculptures with the Doctors of the Church that were originally placed on both sides of the central panel were removed and are now walled in the baptismal font. I will discuss this artwork in detail in an essay that I will be publishing soon.

${ }^{7}$ Indeed, the altarpiece can be compared to the reredos kept at the National Museum of Iceland in Reykjavik, commissioned for the Cathedral of Hólar and carved between 1450 and 1470; and to the Swansea altarpiece of the Victoria and Albert Museum in London, done around 1450. On these artworks: F. CHEETHAM, op. cit. (n. 4), pp. 44, 70-71; on the Swansea altarpiece: European Sculpture at the Victoria and Albert Museum, ed. by P. Williamson, London, 1996, p. 65.
} 
to Liguria in 1551 by a local nobleman, Pietro Giulio Cristiani, who gave them as a gift to the church of San Giovanni Battista in Varese Ligure, his home town, in order to save them from the destruction they would have faced in England ${ }^{8}$.

Yet, it would be an oversimplification, devoid of any historical basis, to think that all the alabasters now kept in Italy arrived there only after the despoliation of English churches that occurred during the Reformation, although it did play a decisive role in the widespread dissemination of these artworks in Europe and Italy. While it is reasonable to think that the now isolated panels, derived from bigger altarpieces, are indeed the result of the marketing exercise that took place after the Reformation ${ }^{9}$, archival records and the artworks themselves tell a different story, that has only been hinted at thus far, and that shows Italy as a purchaser of alabaster carvings from dates much earlier than those of the Reformation. In doing so, the Peninsula took advantage of its many ports and the commercial vocation of many of its cities and people. The flow of goods took place in two directions, that is to say both by Italian buyers in England ${ }^{10}$ and by English merchants active in the Mediterranean as well ${ }^{11}$.
The pieces kept in Italy have almost been neglected thus $\mathrm{far}^{12}$. Yet, their analysis constitutes an essential step to deepening the phenomenon of the diffusion and reception of English alabasters in Europe, as well as of matters connected to the wider historical and cultural context. Indeed, thanks to the diverse-and often prestigious-patrons that commissioned these artworks, and the different arrangements in which they were displayed in the sacred space, the study of the carvings held in Italy can bring a new perspective on our knowledge of functions, typologies, and spatial arrangements of these artworks. The frequent reference of the sources, often aware of the material used to carve the altarpieces, testifies on the one hand to the interests that these artworks could spark in the viewers, and on the other provides a vital historical background.

If some of the alabaster artworks mentioned in archival records, such as the 'Imaginem beate Marie cum eius filio Ihesu Christo de alaubastro' bequeathed by Battagli da Rimini on 16 August 1345 to the Franciscans of Venice to be placed in a chapel within their church, and now lost ${ }^{13}$; the 'Beata Vergine col Figlio in braccio di Alabastro' bequeathed

\footnotetext{
${ }^{8}$ The Virgin and Child is still held within the church of San Giovanni Battista, while the carving with the Trinity is now kept at the Museo Diocesano in La Spezia. A well detailed account on the transfer of these artworks from England to Italy is offered by an eighteenth century manuscript, made known by Ratti in M. RATTI, in Arte e devozione in Val di Vara, Exhibition catalogue (Varese Ligure, July-October 1989), ed. by M. Ratti, Genoa, 1989, pp. 51-54. For a discussion on both the sculptures, see: F. CERVINI, Alabastri inglesi nella Liguria del Quattrocento, in Bollettino dei Musei Genovesi, 12, 1991 (1993), nn. 37-39, pp. 49-63; ID, Alabastri inglesi tra Genova e Savona, in Genova e l'Europa atlantica. Opere, artisti, committenti, collezionisti. Inghilterra, Fiandre, Portogallo, ed. by P. Boccardo, C. Di Fabio, Cinisello Balsamo, 2006, pp. 49-57: 49.

9 This is the case of many panels scattered in several Italian regions, both in churches and in private and public collections as well. In particular: in present Lombardy, the panel with the Tree of Jesse at the Museo Bernareggi in Bergamo, that comes from the parish church of Mediglio, Botta di Sedrina, in the nearby of Bergamo (cfr. Museo Diocesano di Bergamo. Catalogo, ed. by L. Pagnoni, Bergamo, 1978, p. 11, n. 45; Museo Diocesano Adriano Bernareggi in Bergamo. Guida storico-artistica, testi di S. Facchinetti, Cinisello Balsamo, 2008, pp. 24-25, n. 2). Again in Lombardy, the carving with the Adoration of the Magi now in the sacristy of the church of Santa Maria Assunta in Endenna, formerly on the altar of the Magi (cfr. L. PAGNONI, Le chiese parrocchiali della diocesi di Bergamo. Appunti di storia e arte, Bergamo, 1974, 2 vols., I, p. 175). Two carvings are held in Milan, both in private collections: a triptych with the Head of St. John the Baptist and another triptych with the Passion of Christ (cfr. R. PAPINI, Tre sculture inglesi del Quattrocento a Milano, in Rassegna d'Arte, 10, 1912, pp. 160-161). In present Liguria, a sculpture of St. Anne teaching the Virgin to read formerly in a private collection and recently auctioned off in Genoa (Aste Antiquariato Boetto, Asta di Antiquariato e Pittura sec. XIX, 23/02/2015, lotto 782); another carving with the Crucifixion belongs to the diocese of Genoa, and is mistakenly ascribed to a Lombard workshop. Again a Crucifixion is kept at the Museo Civico di Castello Ursino in Catania, formerly in the collection of the Benedictine monks of that same city (cfr. S. BOTTARI, Un alabastro inglese nel Museo Civico di Catania, in Siculorum Gymnasium, 1949, pp. 114-117). A panel with the Nativity is held in the church of the convent of the Capuchins in Giffoni Valle Piana, in the province of Salerno (it is mentioned in G. BENINCASA, Il paliotto in alabastro del XV secolo nella collegiata di Maiori, in Rassegna del Centro di Cultura e Storia Amalfitana, 20, 2000 (2001), 19/20, pp. 161-192: 166). Finally, two carvings were recently reported in Emilia: they both depict the Crucifixion and were both formerly held in the Galleria Fornaro Gaggioli (Mirabilia. Secoli XII-XIV, Exhibition catalogue (Bologna, October 2012), ed. by F. Gualandi, with comments by S. Castri, G. Gentilini, L. Mor, Bologna, 2012, pp. 32-33, n. 9; Thesaurus. Secoli VI-XVI, Exhibition catalogue (Bologna, October 2014), ed. by F. Gualandi, with comments by S. Castri, G. Gentilini, D. Lucidi, Bologna 2014, pp. 24-27, n. 8). A Head of St. John the Baptist, carved at the beginning of the $15^{\text {th }}$ century and now held in the Pio Istituto Elemonisiere in Venzone, comes from the local church of San Giovanni Battista where it was once affixed on the upper part of the wooden altarpiece of the Pozzo family, commissioned in 1661. It is unknown whether the carving was commissioned specifically for that church, where it might have been displayed on the main altar and then acquired by the Pozzo for their private chapel, or if it arrived there at a later date, which seems more plausible to me (cfr. F. FRUCCO, La testa di san Giovanni Battista in disco. Testimonianze in Friuli tra Gotico e Rinascimento, Udine, 2015, pp. 67-78).

${ }^{10}$ That is the case of the two brothers Giorgio and Raffaele Ardizzone, who around 1450 bought in London an 'Icon seu palla altaris quae est in multis quadris, fabricata fuit Londini in Anglia' (i.e. an altarpiece that consists of several panels and that was made in London, England) to be placed on the altar of their family chapel in the church of San Domenico in Taggia, Liguria now lost. Although the description of the altarpiece is not explicit, it is likely that it was an alabaster altarpiece. Cfr. N. CALVINI, La Cronaca dei Calvi. Il Convento dei PP. Domenicani e la Città di Taggia dal 146o al 1623, Taggia, 1982, p. 104; F. CERVINI, op. cit. (n. 8), pp. 54-55; ID., op. cit. (n. 8), pp. 52-55.

"Numerous trade ships from England circulated all over the Mediterranean. We know for sure that they traded many artworks and alabaster sculptures as well, as is confirmed by a petition related to a case of piracy, that informs us that 'Henry Mayn and William Mayn his brother, merchants of Dartmouth [...] on the 1oth day of August in the 14th year of our lord King Richard [1390] loaded at Darmouth a ship called the "George" with woolen cloth of divers colours, images of alabaster and other merchandise, to the value of $£$ 1,0oo, in order to have crossed the sea towards the parts of Great Seville'; Select Cases in Chancery A.D. 1364 to 1471, ed. by W. Paley Baildon, London, 1896 (Publications of the Selden Society X), pp. 45-46. According to Hildburgh, Seville shall not be considered the only destination of the ship; on the contrary, it was probably just one of many stops that merchants did to sell their products (W. L. HILDBURGH, Some Presumably Datable Fragments of an English Alabaster Retable, and some Assembled Notes on English Alabaster Carvings in Spain, in The Antiquaries Journal, 24, 1944, pp. 27-37:34).

${ }^{12}$ After the pioneering essays by Papini (R. PAPINI, op. cit., (n. 5)) and Hildburgh (W. L. HILDBURGH, Some English Medieval Alabaster Carvings in Italy, in Antiquaries Journal, 35, 1955, pp. 182-186), who attempted an analytical survey of English alabasters in Italy, scholars have focused only on specific pieces, often isolating them from the wider context and failing to connect them with the other existing carvings.

${ }^{13}$ The testament is held in the Archivio di Stato di Venezia (henceforth cited as ASVe), Procuratori di San Marco. Misti, b. 291. It is also mentioned in B. CECCHETTI, Nomi di pittori e lapicidi antichi, in Archivio Veneto, 23, 1887, pp. 43-59: 58; W. WOLTERS, La scultura veneziana gotica (1300-1460), Venice,
} 1976, 2 vols., I, pp. 45, 102, 136 note 18. 
by Brother Fallione da Vazzola in 1347 to the church of San Nicolò in Treviso, now also lost ${ }^{14}$; as is the alabaster Crucifixion gifted by Giovanni Trevisan to the church of Santa Maria della Misericordia in Venice ${ }^{15}$, might have been carved in France, where alabaster was also abundantly used ${ }^{16}$, we can be sure that other alabaster artworks that reached Italy from an early date were produced in England instead, in the area between Nottingham, Burton-on-Trent, Leicester and Newark where the majority of quarries used to be ${ }^{17}$.

Among the English alabasters that arrived very early in Italy there are the sculptures which were shipped to Rome in 1382. In that year Cosmato Gentili, Pope Urban VI's representative in England, got an export license for three large alabaster sculptures to be shipped from the city port of Southampton. We are informed by the documents that these sculptures represented the Virgin and Child, St. Peter and St. Paul, plus a smaller image of the Trinity ${ }^{18}$. Two of them, St. Peter and St. Paul," may be those formerly in the church of Santa Croce in Gerusalemme in Rome, now on display at the Museo della Basilica (fig. 1) ${ }^{19}$. Their style is indeed consistent with carvings done around 1380 , as a comparison with the sculptures found in 1779 under the chancel floor of the church of St. Peter in Flawford and now kept at the Castle Museum in Nottingham, demonstrate ${ }^{20}$.

The original setting of the sculptures in Rome is still a matter of discussion. However, in 1894 during the recovery of some fragments of the old ciborium of the Basilica, completed in 1140 and broken up in the eighteenth century ${ }^{21}$, the superintendent stated that the 'two exquisite statues of St. Peter and Paul, that Passalacqua placed on both sides of the subterranean altar in front of that entitled to St. Helen' belonged originally to the ciborium ${ }^{22}$. We do not know how the sculptures were fixed to it, and which part of the ciborium they adorned. The figures of St. Peter and Paul were surely functional to visually represent the papal authority, and perfectly lend themselves to be displayed in one of the most prestigious churches of Rome, traditionally thought to have been founded by St. Helen and site of papal annual processions. The symbolic meaning must have been particularly relished by Urban VI, an active proponent and promoter of the return of the apostolical seat from Avignon to Rome.

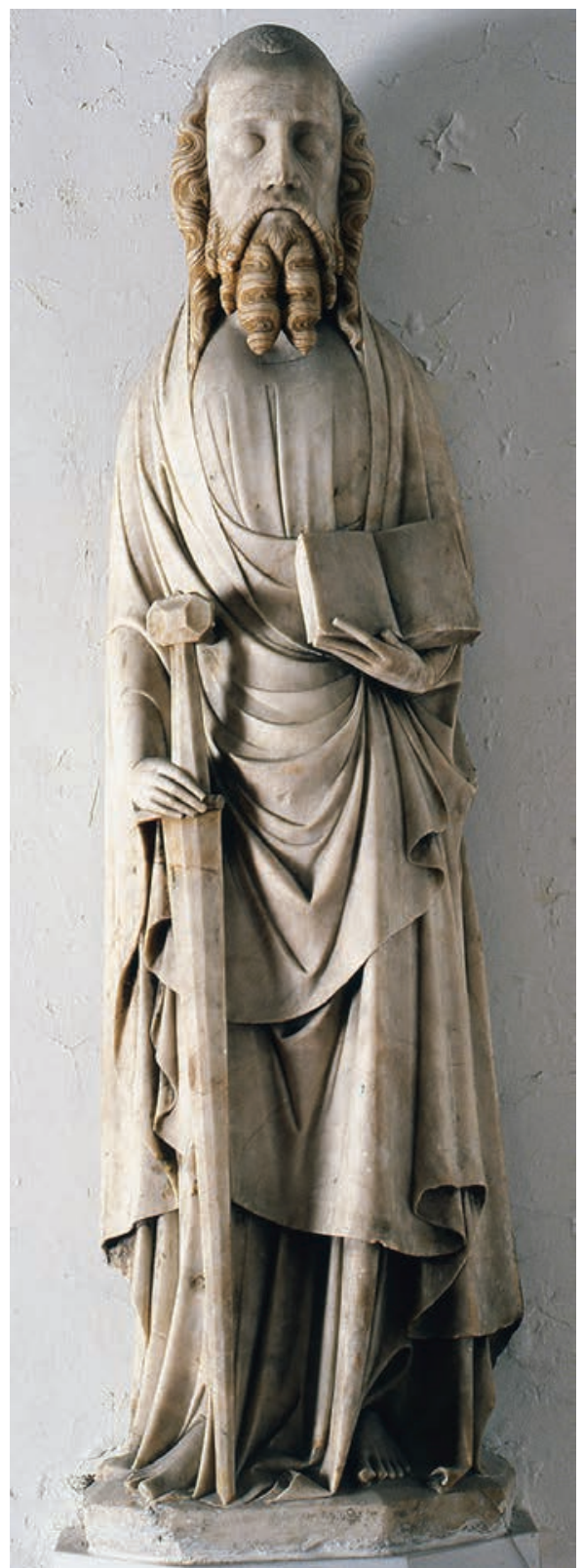

Fig. 1: St. Paul; Rome, Museo della Basilica di Santa Croce in Gerusalemme

${ }^{14}$ For brother Fallione's bequest: D. M. FEDERICI, Memorie trevigiane sulle opere di disegno. Dal mille e cento al mille ottocento, Venice, 1803 , 2 vols., I, p. 38. Cfr. also W. WOLTERS, op. cit. (n. 13).

${ }^{15}$ On 4th March 1431 a box decorated with vegetal ornamentations was commissioned, to be used to cover and protect the carving. See P. PAOLETTI, L'Architettura e la scultura del Rinascimento a Venezia, Venice, 1893, 2 vols., I, pp. 91, 17; W. WOLTERS, op. cit. (n. 13), p. 136 note 18.

${ }^{16} \mathrm{Cfr}$. W. WOLTERS, op. cit. (n. 13), p. 136 note 18. This might have also been the case of the 'Cristo passo de alabastro', i.e. the alabaster Man of Sorrows, that the Venetian Agnesina della Stoppa mentions in her will of 1422 (ASVe, Cancelleria inferiore. Notai, b. 24, fol. 27v, n. 201; cfr. F. SORELLI, Per la storia religiosa di Venezia nella prima metà del Quattrocento: inizi e sviluppi del terz'ordine domenicano, in Viridarium Floridum: studi di storia veneta offerti dagli allievi a Paolo Sambin, ed. by M.C. Billanovich, G. Cracco, A. Rigon, Padua, 1984, pp. 89-113: 102 note 35). Indeed, the Man of Sorrows iconography seems to have been unpopular in England, while it was common in many other European regions. The existence of French alabasters in Venice is exemplified by the Virgin and Child kept in the sacristy of the church of Santo Stefano (cfr. T. FRANCO, in I Tesori della Fede. Oreficeria e Scultura dalle Chiese di Venezia, Exhibition catalogue (Venice, March-July 2000), ed. by S. Mason, R. Polacco, Venice, 2000, pp. 57-58, n. 19).

${ }^{17}$ See F. CHEETHAM, op. cit. (n. 4), pp. 13-17; F. CANNAN, "If Marble will not Serve”. Medieval English Alabaster Sculpture, from Quarry to Object of Devotion, in Object of Devotion, op. cit. (n. 3), pp. 22-37.

${ }^{18}$ W. L. HILDBURGH, op. cit. (n. 12), p. 186, pl. XXX; F. CHEETHAM, op. cit. (n. 4), p. 41, fig. 22; P. WILLIAMSON, Introduction, in Object of Devotion, op. cit. (n. 3), pp. 12-21: 14 .

${ }_{19}$ U. MIDDELDORF, Two English Alabaster Statuettes in Rome, in Art in America, 16, 1927-1928 (1928), p. 201; W. L. HILDBURGH, op. cit. (n. 12), pp. 185186; C. F. PITMAN, Speculations on fourteenth-century English alabaster work, in The Connoisseur, 155, 1964, 624, pp. 82-89: 88.

${ }^{20}$ On the sculptures of Nottingham: F. CHEETHAM, Medieval English Alabaster Carvings in the Castle Museum, Nottingham, Nottingham, 1973, pp. 18-25; ID, op. cit. (n. 12), p. 41.

${ }^{21}$ P. C. CLAUSSEN, Magistri doctissimi Romani: die römischen Marmorkünstler des Mittelalters, Stuttgart, 1987, pp. 14-16; C. VARAGNOLI, S. Croce in Gerusalemme: la basilica restaurata e l'architettura del Settecento romano, Rome, 1995, p. 22.

${ }^{22}$ A. M. AFFANNI, Storia dei restauri attraverso lo studio dei documenti d'archivio, in La Basilica di Santa Croce in Gerusalemme a Roma: quando l'antico è futuro, ed. by A. M. Affanni, Rome, 1997, pp. 103-114: 106-107. Some inventories written between 1786 and 1859 recorded the sculptures in the chapel of St. Helen, where they flanked the sculpted effigy of the saint. Starting from 1860 they were placed at both sides of the altar entitled to the Piety, in the 


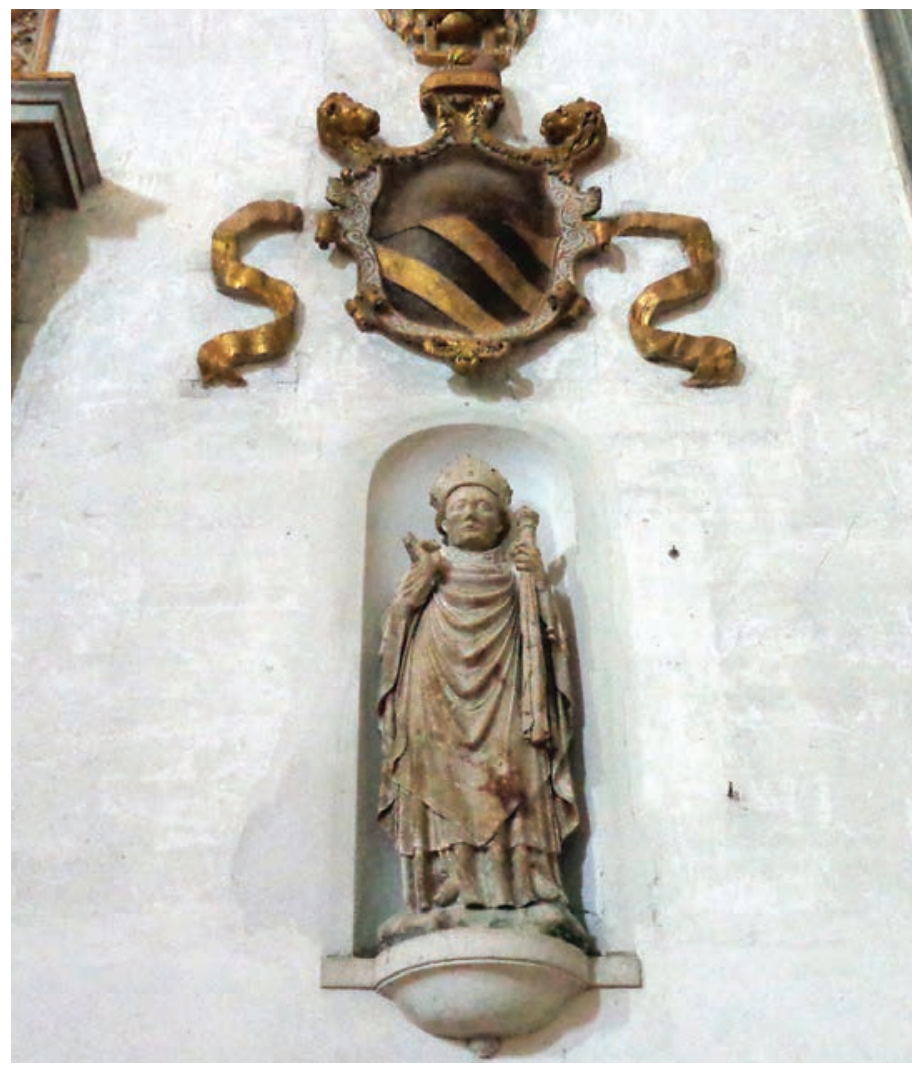

Fig. 2: Bishop Saint; Venice, Church of San Francesco della Vigna

The pope also started an integral renovation of the church of Santa Croce in 1370, entrusting its management to the Carthusians ${ }^{23}$. This interest he shared with Cosmato Gentili, who was created presbyter cardinal of the church of Santa Croce on 18 December 1389, and who was later elected pope with the name of Innocent VII ${ }^{24}$. In England, where Cosmato was sent to admonish Canterbury and York ${ }^{25}$, he was in touch with the highest hierarchies of the reign, and with the King himself. We shall remember, therefore, that during those years alabaster was very popular at the English court, and that in 1367 King Edward III commissioned Peter the Mason of Nottingham the execution of an alabaster altarpiece to be placed in the chapel of St. George at Windsor, now $\operatorname{lost}^{26}$.

A sculpture in Venice is very similar to the carvings in Rome, both from a compositional and from a stylistic point of view. It is the Bishop Saint, usually identified as Louis of Toulouse, set in a niche high on the left wall of the presbytery of the church of San Francesco della Vigna, close to the door that leads to the sacristy and the convent (fig. 2). The story of this sculpture is unknown. We know for sure that it was

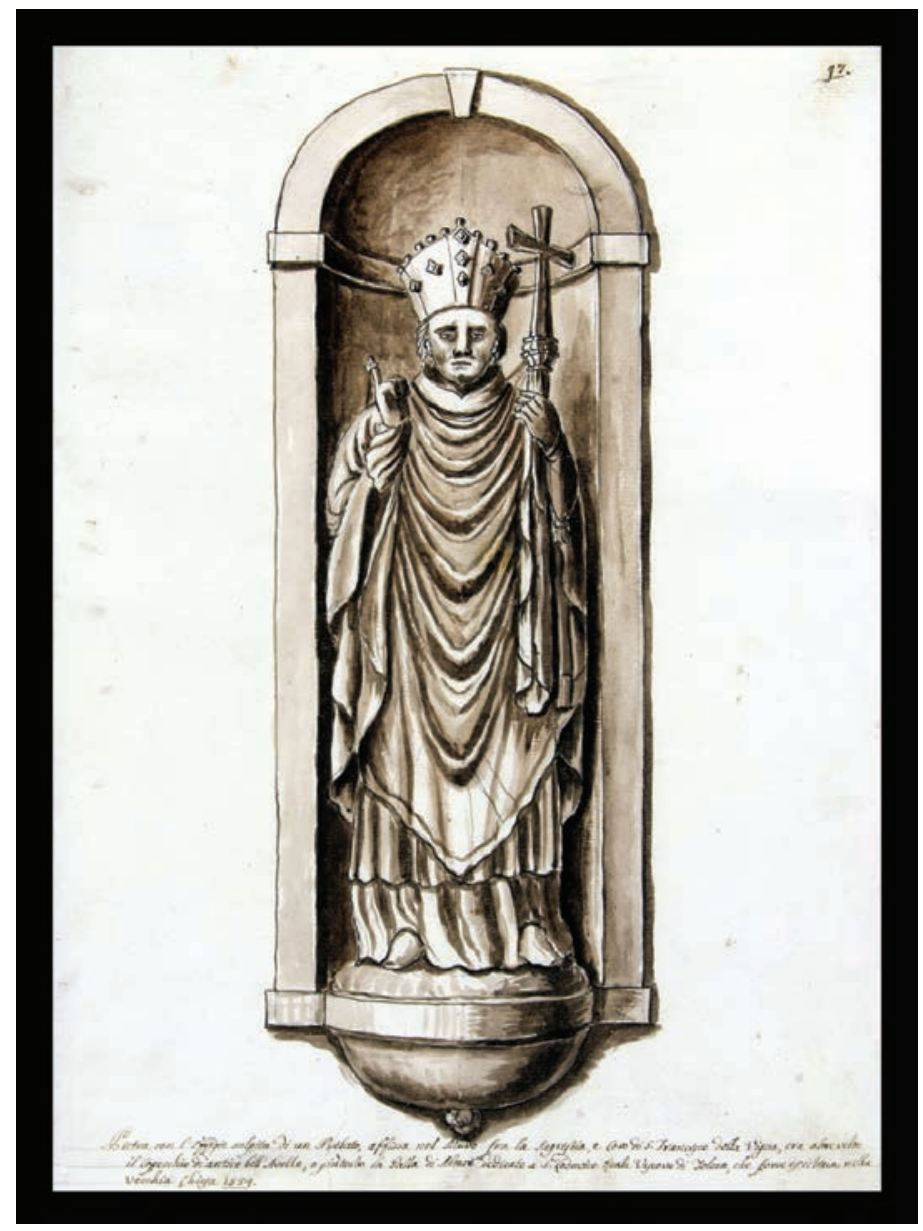

Fig. 3: J. Grevembroch, Monumenta Veneta ex antiquis ruderibus templorum, aliarumque aedium vetustate collapsarum collecta, 1754, Venice, Museo

Correr, MS Gradenigo-Dolfin 208, I, fol. 97

already in the church, and precisely in its current position, in 1754. Indeed, in that year Johannes Grevembroch saw, described, and drew it (fig. 3) ${ }^{27}$. According to Grevembroch, the sculpture might have decorated originally the cover of a funerary monument, or have constituted the furnishing of an altar devoted to St. Louis of Toulouse which used to be placed in the Gothic church, the ancient church enlarged from $1534^{28}$. A faulty interpretation of Grevembroch's words, together with a mistaken reading of ancient sources, which mention a sepulchre with the remains of Louis King of Sicily in the vestibule of the ancient church ${ }^{29}$, has led Wolters to hypothesise that a funerary monument of St. Louis of Toulouse did exist in the church and that Grevembroch implied that the alabaster sculpture was used indeed to cover that tomb ${ }^{30}$. However,

Gregorian chapel near that of St. Helen (D. RADEGLIA, Le statue in alabastro di San Pietro e San Paolo, Ivi, pp. 137-140: 137 fig. 1, 140; see also S. ORTOLANI, S. Croce in Gerusalemme, Rome, 1924 (Le chiese di Roma illustrate, 6), fig. 16).

${ }_{23}$ Cfr. M. ARMELLINI, Guide de Rome, dédié aux pèlerins venus pour visiter le tombeau du Prince des Apotres, Rome, 1887, p. 205; S. ORTOLANI, op. cit. (n. 22), p. 16.

${ }^{24}$ For an account on Cosmato's biography: A. DE VINCENTIIS, s.v. Innocenzo VII, papa, in Dizionario Biografico degli Italiani, 62, Rome, 2004, pp. 447-450. ${ }^{25}$ Ibidem.

${ }^{26}$ Cfr. Issue Roll, 42, Edward III (1367/8-1368/9); W. H. ST. JOHN HOPE, On the Early Working of Alabaster in England, in Archaeological Journal, 61, 1904, pp. 220-240: 224-225; F. CHEETHAM, op. cit. (n. 4), p. 13.

${ }_{27}^{27}$ JOHANNES GREVEMBROCH, Monumenta Veneta ex antiquis ruderibus templorum, aliarumque aedium vetustate collapsarum collecta, 1754, Venice, Biblioteca del Museo Correr, MS Gradenigo-Dolfin 208, I, f. 97. The sculpture is also mentioned in Memorie del convento e chiesa di S. Francesco della Vigna in Venezia. Compilate nel 1898 dal P. Leone Ranzato, Venice, Biblioteca di San Francesco della Vigna, conv. 271.931.7.RAN.1-4, I, cc. 379-38o.

${ }^{28}$ Grevembroch's inscription reads: "Pietra con l'effigie scolpita di un Prelato, affissa al Muro fra la sagrestia e coro di San Francesco della Vigna, era altre volte il coperchio di antico bell'Avello, o più tosto la Palla di Altare dedicato a San Ludovico Reale Vescovo di Tolosa, che forse esisteva nella vecchia chiesa 1534".

${ }^{29}$ M. SABELLICO, De situ urbis libri tres, Venice, 1502; F. SANSOVINO, Venetia città nobilissima et singolare. Descritta già in XIIII Libri da M. Francesco Sansovino, et hora con molta diligenza corretta, emendata, e più d'un terzo di cose nuove ampliata dal M. R. D. Giovanni Stringa, Venice, 1604, f. 115r; F. CORNER, Ecclesiae Venetae Antiquis monumentis nunc etiam primum editis illustratae, Venice, 1749, XI/2, p. 15.

$3^{\circ}$ W. WOLTERS, op. cit. (n. 13), p. 202, n. 112. 


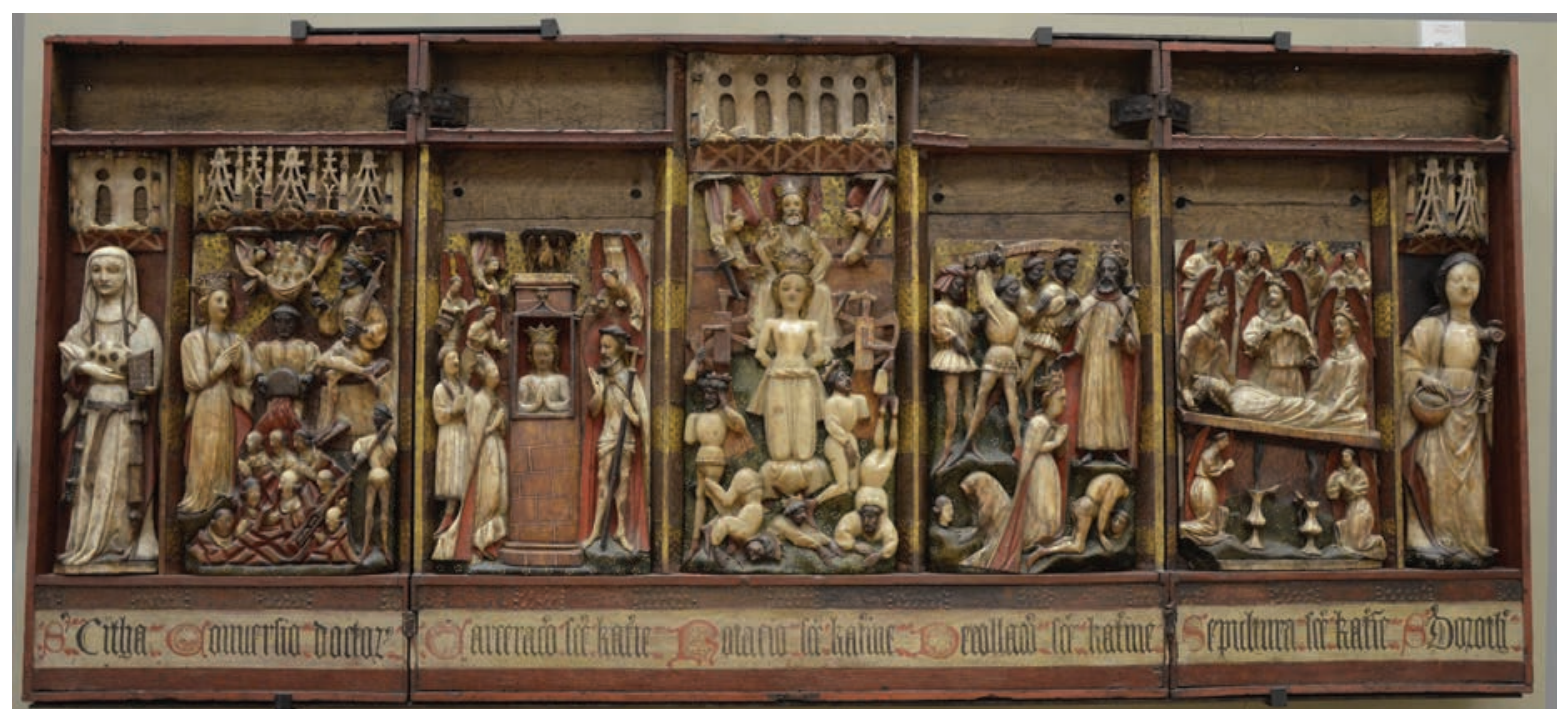

Fig. 4: Triptych of St. Catherine; Venice, Galleria Franchetti alla Ca' d'Oro

Grevembroch did not refer to that sepulchre, which was not mentioned by previous sources either. On the contrary, he mentioned a generic tomb, which was no longer in existence. Yet, the sculpture seems to have been conceived as a standing figure from the beginning, therefore it was probably destined for the decoration of an altar ${ }^{31}$. One cannot exclude that it was a pillar picture, that is to say a devotional image not attached to an altar but to a pillar or a column instead, a use that is testified for some alabaster carvings ${ }^{32}$. From an iconographic point of view, it should be remarked that the habit in which the bishop saint is dressed is not the Franciscan coarse woolen cloth usually worn by Louis of Toulouse, and we shall thus speculate that the identity of the saint is another. His conventional symbols are not sufficient to identify him: the opulent mitre and the crosier (now fragmentary, but originally decorated with a cross, still visibile in Grevembroch's drawing), are indeed too generic to enable an identification.

The good quality of the carving, embellished by a rich polychromy and gilding, may imply that the sculpture was commissioned -or bought- by a wealthy and distinguished patron. Additionally, the prestigious position of the sculpture, placed in an elevated niche near the door that leads to the sacristy and the convent, a location that ensured great visibility and daily attention by the friars who passed near it while entering the cloister, seems to go in that same direction. In line with the sculpture, and above it, there is a showy crest that seems to create some sort of a complement to the sculpture, to the point that I would not exclude that there was a link between them ${ }^{33}$. After all, the church and the convent were beneficed by the wealthiest families in town, many of which had their tombs and funerary chapels there ${ }^{34}$. We can imagine that one of these families ordered the English sculpture, taking advantage of the commercial and financial relations that many Venetians had with the North. After the renovation of the church in the sixteenth century, the sculpture might have been relocated within the new church, a practice that is testified for other artworks that have been moved from the older building into the new one ${ }^{35}$.

The fact that Venice and the Venetians were early buyers of English alabasters is testified by other sculptures both in the city and in the mainland.

A polyptych now on display at the Galleria Franchetti alla Ca' d'Oro in Venice (fig. 4) testifies to the purchase of magnificent artworks from England. It is an alabaster triptych with closing wings that shows scenes from the Life of St. Catherine flanked by the saints Zita and Dorothy ${ }^{36}$. It still preserves its original carpentry, enriched with inscriptions in Gothic characters that identify the subjects represented above ${ }^{37}$. From a stylistic and typological point of view, the triptych can be compared to artworks such as the Swansea Altarpiece in the Victoria and Albert Museum (1450 c. $)^{38}$, and

${ }^{31}$ The archival research I have conducted thus far failed to provide information on the possible original arrangement of the sculpture. The situation is made much more complicated because of the destruction of the original church, replaced by a new one in the $16^{\text {th }}$ century. The archival records are held in ASVe, San Francesco della Vigna. A transcription of some documents is provided in Memorie del convento, op. cit. (n. 27).

${ }^{32}$ That is the case of the sculpture of St. Anne in the church of Daventry, before which Edward IV knelt on Palm Sunday 1471. The detailed chronicle records 'in a pillar of the churche, directly aforne the place where [the] Kynge knelyd, and devowtly honoryd the Roode, was a lytle ymage of Seint Anne, made of alleblaster, standynge fixed to the piller'. Historie of the arrivall of Edward IV in England and the finall recoverye of his Kingdomes from Henry VI, A.D. MCCCCLXXI, ed. by J. Bruce, Camden Society, 1838, p. 14; P. NELSON, The Woodwork of English Alabaster Retables, in Transactions of the Historic Society of Lancashire and Cheshire, 72, 1920, n.s. XXXVI, pp. 50-60: 58-59.

33 I have not been able to identify the crest thus far. Many surveys of Venetian blasons exist; see, for instance, Stemmario Veneziano Orsini De Marzo, Milan, 2007. ${ }^{34}$ For some information on the dynamic patrician patronage within the church of San Francesco: ASVe, San Francesco della Vigna. Obblighi perpetui, b. 3 , fasc. 2; Memorie del convento e chiesa, op. cit. (n. 27).

${ }^{35}$ For instance, Andrea Bragadin's tomb: ASVe, San Francesco della Vigna. Obblighi perpetui, b. 3, fasc. 2, c. 14r; Memorie del convento, op. cit. (n. 27).

${ }^{36}$ On this triptych, that measures 83 x $190 \mathrm{~cm}$ : P. NELSON, op. cit. (n. 32), p. 52; M. CIARTOSO LORENZETTI, Il polittico in alabastro della chiesa di Santa Caterina, in Annuario del Liceo Foscarini, 1928, pp. 9-17; W. WOLTERS, op. cit. (n. 13), p. 139 n. 33; S. MOSCHINI MARCONI, Note per la chiesa di Santa Caterina, in Quaderni della Soprintendenza ai Beni Artistici e Storici di Venezia, 7, 1978, pp. 31-39; A. AUGUSTI, in Pisanello. I luoghi del Gotico Internazionale, Exhibition catalogue (Verona, September-December 1996), ed. by F. M. Aliberti Gaudioso, Milan, 1996, p. 330; Ca' d'Oro. La Galleria Giorgio Franchetti, ed. by A. Augusti, F. Saccardo, Milan, 2002, p. 17, n. 21.

37 The inscriptions read: S(ancta) Citha; Conversio doctor(um); Carcerac(i)o S(an)c(t)e Kat(er)i(n)e; Rotatio S(an)c(t)e Kat(er)ine; Decollati(o) S(an)c(t)e Kat(er)ine; Sepultura S(an)c(t)e Kat(er)i(n)e; S(ancta) Doroth(ea).

${ }^{3} \mathrm{Cfr}$ supra, n. 7. 
the fragmentary polyptych of St. Catherine in the church of St. Mary at Fontarabia (1430-1450 ca.) ${ }^{39}$.

The triptych entered the museum after the Napoleonic suppressions. Before that, it formed part of the furnishing of the Augustinian female church of Santa Caterina de' Sacchi in Venice. The numerous re-fittings of the church, only rarely documented with precision, and the several restorations, prevent the reconstruction of the original setting of the triptych. In 1581, Sansovino saw it on the altar of the Angel Raphael, in the right nave of the church, where it was used as a predella ${ }^{40}$. The altar was funded and endowed by Zuan Antonio Nasi, who mentioned it in his testament of $1567^{41}$, where he also asked for a tomb to be completed and placed in front of his altar for himself and his family members ${ }^{42}$.

However, it is unclear whether that was the original location of the triptych or not, and the situation is much more complicated than it might appear to be. Indeed, Zuan Antonio Nasi took pains to bequest a legacy to decorate the altar with marble colonettes and a font for holy water, and to provide it with stairs. He also bequeathed the altar a painting that depicted the Supper at Emmaus, which hung in his bedroom at the time of his will ${ }^{43}$. In his testament, thus, there is no mention of the alabaster triptych, while later sources, starting from Ridolfi (1648) ${ }^{44}$, assured that the altar was decorated with the painting of Tobias and the Angel by Titian, now kept at the Gallerie dell'Accademia in Venice, which is however adorned with the Bembo coat of arms, and that must have been placed there at a later time ${ }^{45}$. After all, the iconography of the alabaster triptych is not consistent with the dedication of the altar. Furthermore, if we consider the fact that the alabaster was carved a century before Sansovino saw it on that altar, the suspicion that it was a later setting is supported.
In my opinion, we shall thus reflect on the circumstance that a scuola piccola, a confraternity, dedicated to St. Catherine existed within the church. Founded in 1337, it had its site in a two-floor building near the convent. Not only did the confraternity own an altar on the second floor of the Scuola, but also that of St. Catherine in the left nave of the church $^{46}$, together with two richly decorated funerary monuments for the brothers and sisters on the counter-façade of the church ${ }^{47}$. Furthermore, the inventories of the goods that belonged to the confraternity, written from 1399, mentioned several altar furnishings and decorations -both movable and unmovable- embellished with the representation of the Alexandrine saint, placed inside the church and also in the locations reserved for the members, which seem to have fostered a sort of monopoly on the image of the saint ${ }^{48}$. I wonder therefore, if the alabaster polyptych might have originally been linked to the confraternity rather than to Zuan Antonio Nasi. One may wonder if the alabaster triptych can be identified with the large altarpiece of St. Catherine placed on the upper hall of the Scuola, where there was an altar on which a chaplain celebrated mass and new brothers and sisters swore observance to the rules ${ }^{49}$. If so, it might have been dismantled and moved in a later time, perhaps after 1489, when the first Scuola was demoted to a storage facility while a new, larger, building was erected next to and in front of the church. After all, because of their emotional character, capable of raising in the beholder a strong affective and empathetic reaction, thanks to the symbolic use of colour and to the numerous realistic details ${ }^{50}$, alabaster polyptychs were much appreciated by confraternities. In this respect, we shall consider the polyptych with the Passion of Christ now at the Museo Nazionale del Molise di Castello Pandone, which came from the church of the Santissima Annunziata in Venafro ${ }^{51}$. It was originally placed on the altar of the

39 E. MACLAGAN, An English Alabaster Altarpiece in the Victoria and Albert Museum, in The Burlington Magazine for Connoisseurs, 36 , 1920, 203, pp. 53-65: 62, 59 Pl. II, C; G. STUDER, X. MARTIARENA, Conservación y restauración de cuatro alabastros de Santa María del Manzano de Hondarribia, in Akobe: restauración y conservación de bienes culturales, 8, 2007, pp. 77-81; X. MARTIARENA LASA, Los alabastros ingleses en Gipuzkoa. El retablo de Santa Catalina de Hondarribis, in Ars Bilduma. Revista del Departamento de Historia del Arte y Música de la UPV, 2, 2012, pp. 35-47.

${ }^{40}$ F. SANSOVINO, Venetia città nobilissima et singolare descritta in XIIII Libri, Venice, 1581, f. 61v; F. SANSOVINO, op. cit. (n. 29), f. 149v.

${ }^{41}$ The testament is kept at the Archivio Patriarcale di Venezia (henceforth cited as APVe), Archivio "segreto", Visite pastorali monasteri femminili, bb. 4-5, nn. 24, 12; a copy can be found in ASVe, Notarile, Testamenti, Ziliol, b. 1259, n. 588. The text has been transcribed in F. TOFFOLO, Art and the Conventual Life in Renaissance Venice: the Monastery Church of Santa Caterina de' Sacchi, PhD Thesis, University of Princeton, 2005, pp. 164-167, Appendix b; it is also mentioned in S. FERRARI, in Pietro Bembo e l'invenzione del Rinascimento, Exhibition catalogue (Padova, February-May 2013), ed. by G. Beltramini, D. Gasparotto, A. Tura, Venice, 2013, pp. 206-208, n. 3.18.

${ }^{42}$ The tomb is cited by Cicogna, who records: "IOANNI ANTONIO NASIO VIRO INTEGERRIMO/IOANNIS PAULI FILIO/ AC MAVROCENAE VXORI/ DILECTISSIMAE/ SIBI VIVENTI POSITUM/ MDLXVIII"; Corpus delle Iscrizioni di Venezia e delle isole della laguna veneta, di Emanuele Antonio Cicogna, ed. by P. Pazzi, Venice, 2001, 3 vols., I, p. 302.

${ }^{43}$ For the testament, see supra, n. 41.

${ }^{44}$ C. RIDOLFI, Le maraviglie dell'arte, ovvero delle vite degli illustri pittori veneti e dello Stato, Venice, 1648, pp. 152-153.

${ }^{45}$ S. FERRARI, op. cit. (n. 41).

${ }^{46}$ This altar was lavishly decorated with scuola funds. According to the inventory, it was large and housed a now-lost wooden statue of the Alexandrine saint. A number of other visual elements completed the ensemble. Two wooden angels flanked the saint while a copper "cesendello" burned perpetually before the altar for the salvation of the members' souls. M. CIARTOSO LORENZETTI, La mariegola della scuola di Santa Caterina de' Sacchi a Venezia, in Ateneo Veneto, 5, 1927, pp. 5-53: 50; F. TOFFOLO, op. cit. (n. 38), pp. 121-127.

${ }^{47}$ See M. CIARTOSO LORENZETTI, op. cit. (n. 46); F. TOFFOLO, op. cit. (n. 41), pp. 121-127.

${ }^{48}$ The document is transcribed and published in M. CIARTOSO LORENZETTI, op. cit. (n. 46), pp. 45-53. It mentions five Anchone, or altarpieces, many textiles used as altar-frontals and banners, two tabernacles, reliquaries, boxes, several liturgical objects, books, and altar decorations.

${ }^{49}$ The hall contained an altar decorated with a large altarpiece of St. Catherine (described as 'Anchona una granda de S. Catarina') to be illuminated constantly for the salvation of the members' souls. Precious liturgical objects were used during the services, including a gilded chalice studded with stones, a large silver crucifix, silk and velvet corporals and a missal covered with vermilion leather. M. CIARTOSO LORENZETTI, op. cit. (n. 46), pp. 45-49.

${ }^{50}$ These characteristics are discussed in relation to paraliturgical dramas in W. L. HILDBURGH, English alabaster carvings as records of the medieval religious drama, in Archaeologia or miscellaneous tracts relating to antiquity, 93, 1949, pp. 51-101.

${ }^{51}$ F. VALENTE, Nel borgo medievale di Venafro, in Almanacco del Molise, 1972, pp. 219-244: 238-240; ID., La Cattedrale e le formelle dell'Annunziata. Architettura e scultura tardo gotica nella Venafro del '40o, in Almanacco del Molise, 1977, pp. 220-255: 229-255; D. ARTIOLI, M. LAURENZI TABASSO, G. VIGLIANO, Il Polittico della Passione di Venafro. L'intervento di restauro, in Conoscenze, 3, 1986, pp. 129-146; G. BASILE, Il Polittico della Passione di Venafro. Recupero, restauro, fruizione, Ivi, pp. 109-127; G. BENINCASA, op. cit. (n. 9), pp. 177-178. 


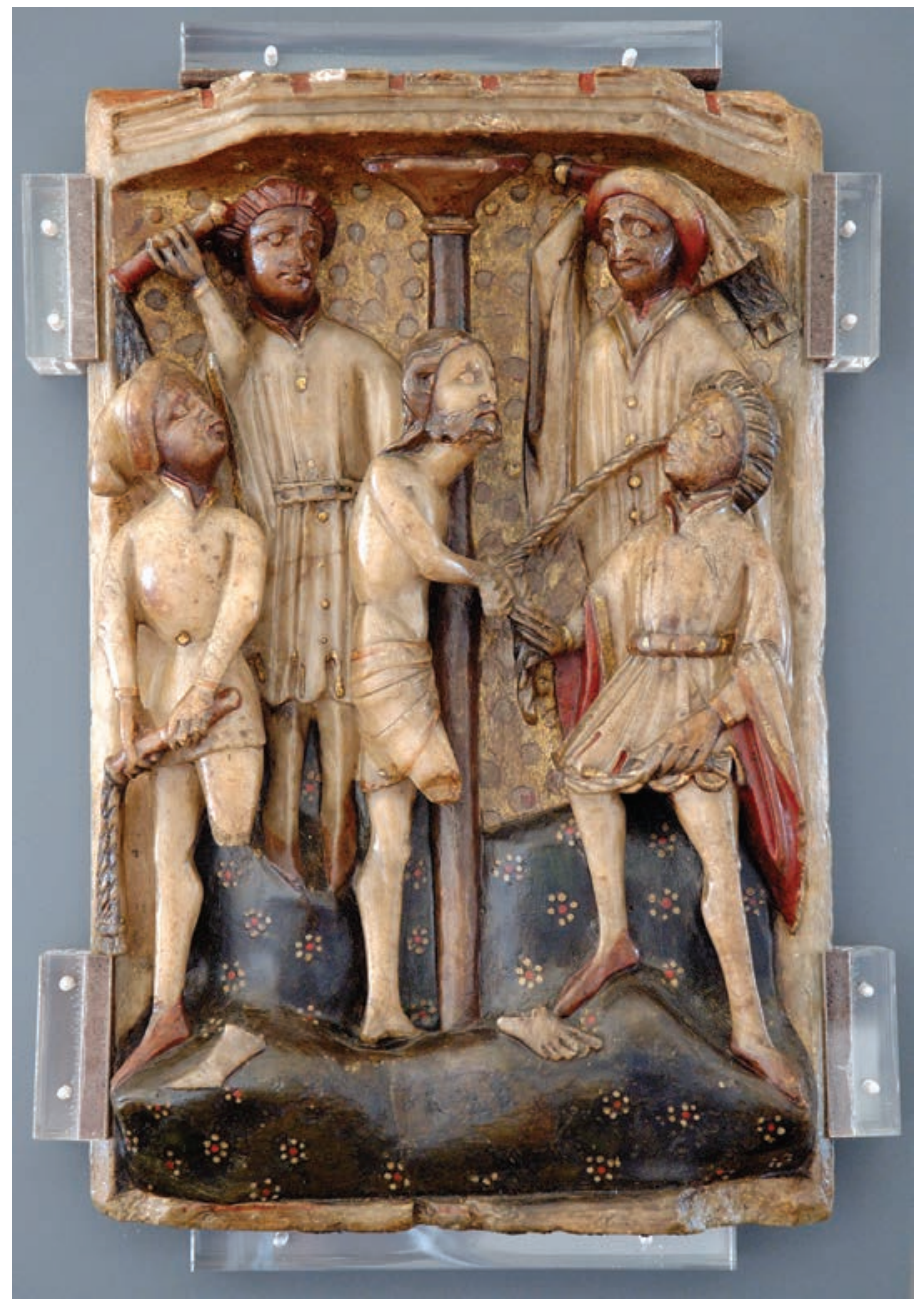

Fig. 5: Christ's Flagellation; Venice, Pinacoteca Manfrediniana del Seminario Patriarcale

Cross, founded by the Flagellants and then brought out by a confraternity close to the Battuti. With its details that show Christ's sufferings, the dramatic use of colours-pitch black for the faces of the executioners, bright white for the faces of Christ and Mary, recurrent sharp red in the carvings-the polyptych perfectly responded to the devotional needs and ideals of the confraternities.

A polyptych very similar to the Ca' d'Oro one, both in terms of iconography and typology, formed part of the collection of Tommaso degli Obizzi in his castle, called Cataio, near Padua, and is now held in the Kunsthistorisches Museum in Wien ${ }^{52}$. It consists of two standing figures of saints Margaret and Apollonia, and four reliefs showing the Legend of St. Catherine. Although the carvings are now separated, and the original frame got lost, yet it is evident that the compositional arrangement of this triptych was very similar to the Ca' d'Oro alabaster, also in terms of the dimensions ${ }^{53}$. The ideal recomposition of the polyptych lacks of the central panel, which must have been bigger than the lateral ones, and that might have shown the Martyrdom of Catherine, as the Venetian triptych. We lack any evidence to reconstruct the history of the polyptych and its original location. However, as we know that during the eighteenth and the nineteenth centuries, Italian collectors as well as Tommaso degli Obizzi, used to buy artworks available in the local market, we might hypothesize that the alabaster altarpiece came from a church in the territory of Padua.

Other alabaster artworks exist in the Veneto, proving the fundamental role played by the port of Venice in the marketing of these sculptures. Again in Venice, in the Pinacoteca Manfrediniana del Seminario Patriarcale, is held a relief that shows Christ's flagellation (fig. 5), that dates back to the first half of the fifteenth century. It likely comes from the Venetian church of Santa Lucia ${ }^{54}$, destroyed between 1860 and 1861. The Flagellation is set against a rocky landscape; the lower ground is painted green, with small clusters of white dots surrounding one red dot, representing flowers. The upper background is gilded, the surface being decorated with applied dots of gesso-now detached-stuck on to the alabaster. These details, together with the battlemented top and the three-sided chamfered base, can be compared to artworks that date back to the beginning of the fifteenth century, such as the Passion altarpiece of the Victoria and Albert Museum in London ${ }^{55}$. From a stylistic and iconographic point of view, the carving can be related to two sculptures now kept at the Museo Diocesano di Arte Sacra in Treviso (figs. 6-7), formerly in the sacristy of the local Cathedral ${ }^{56}$. The carvings show the Deposition and the Resurrection of Christ. Their dimensions are consistent with those of the relief in Venice ${ }^{57}$, and also the treatment of the background and the shape of the slab are very similar. Again, strictly alike is the way in which the faces are done, delicate

\footnotetext{
$5^{2}$ For an account of what happened to the collection of Tommaso degli Obizzi after his death (1803) and the transfer of artworks to Wien: G. TORMEN, Ad ornamentum imperii: il trasferimento della collezione Obizzi a Vienna a fine Ottocento, in Saggi e memorie di storia dell'arte, 34, 2010 (2012), pp. 173-254. The alabaster altarpiece is mentioned in the inventory of Tommaso's collection written in 1806 (published in Documenti inediti per servire alla storia dei Musei d'Italia, III, Oggetti d'antichita e d'arte esistenti al Catajo, Rome, 188o, p. 30, n. 948), and is reproduced in the catalogue of the Estense collection published by Planiscig, together with some photos (L. PLANISCIG, Die Estensische Kunstsammlung. I. Skulpturen und Plastiken des Mittelalters und der Renaissance, Wien, 1919, pp. 45-47, nn. 76-81).

53 The panels now in Wien measure $40 \times 26 \mathrm{~cm}$, while the standing saints on the sides $\mathrm{cm} 40 \mathrm{x} 13$. Thus the altarpiece should have measured approximately 60 (considering that the central panel must have been higher than the later ones, and that a carved frame must have been placed above it) $\mathrm{x} 250 \mathrm{~cm}$.

54 The carving is mentioned in the Museum starting from 1912 (cfr. Guida del visitatore artista attraverso il Seminario Patriarcale di Venezia, Venice, 1912 p. 125), while it is not cited in the catalogue published in 1842 (G. MOSCHINI, La Chiesa e il Seminario di Santa Maria della Salute, Venice, 1842). Therefore, it is likely that it entered the Museum around 1860, with the boxes that came from the church of Santa Lucia, although it is not mentioned in the inventory written on 28 July 1860 before the demolition of the church (the integral text of the inventory, held in APVe, Sezione Moderna, Parrocchie - Venezia, S. Geremia, b. 18/A, II.V.3, n. 39, is published in E. BASSI, Fondamenta Santa Lucia, 1-57, in Atti dell'Istituto Veneto di Scienze, Lettere ed Arti, 152, 1993-1994, Classe di scienze morali, lettere ed arti, pp. 635-654: 647-654). On the carving, see: F. SPADAVECCHIA, in Restituzioni 20oo. Capolavori restaurati, Exhibition catalogue (Vicenza, September-November 200o), ed. by F. Rigon, Vicenza, 2000, pp. 133-137, n. 18; Aprirono i loro scrigni. Pinacoteca Manfrediniana e Opere d'arte del Seminario Patriarcale, ed. by S. Marchiori, Venice, 2008, pp. 68-69, n. 18.

55 On this polyptych: F. CHEETHAM, op. cit. (n. 4), p. 68.

${ }_{56}^{6}$ Coletti saw and described them there in 1935: Catalogo delle cose d'arte e di antichità d'Italia. Treviso, ed. by L. Coletti, Rome, 1935, p. 197, n. 368.

57 The Flagellation of Venice measures 38 x $25 \mathrm{~cm}$, the Deposition and Resurrection of Treviso $40 \mathrm{x} 27 \mathrm{~cm}$ and 41 x 28 respectively.
} 


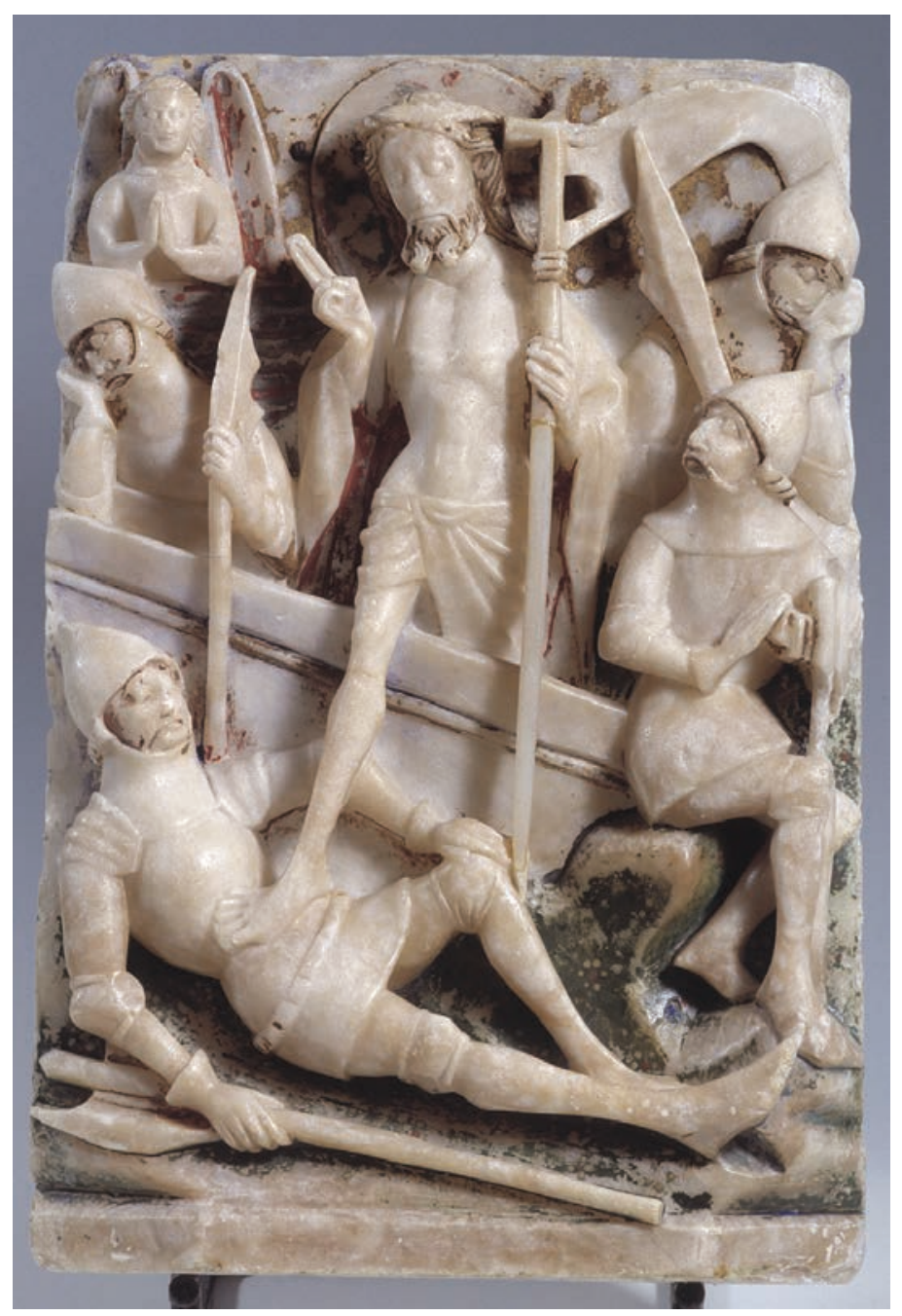

Fig. 6: Christ's Deposition; Treviso, Museo Diocesano di Arte Sacra

and soft, and the hair (figs. 8-11). We may thus be tempted to think that the carvings belonged to the same altarpiece and that, once it had been divided in pieces, the panels took different market directions. Alternatively, we shall hypothezise the existence of two atarpieces of the same subject, i.e. the Passion of Christ, carved by the same workshop around the same years, and both destined to the Veneto.

In the doubt that remains, considering the absence of any specific evidence, it might be worth remembering that a similar fate occurred to other alabaster altarpieces in Italy and elsewhere. Indeed, the independent character of the panels that compose these altarpieces, both from a structural as well as from a narrative point of view, has often made them attractive as free-standing compositions. Among these, there is the 'retable of alabaster with many figures' that an inventory written in 1644 mentions on the altar

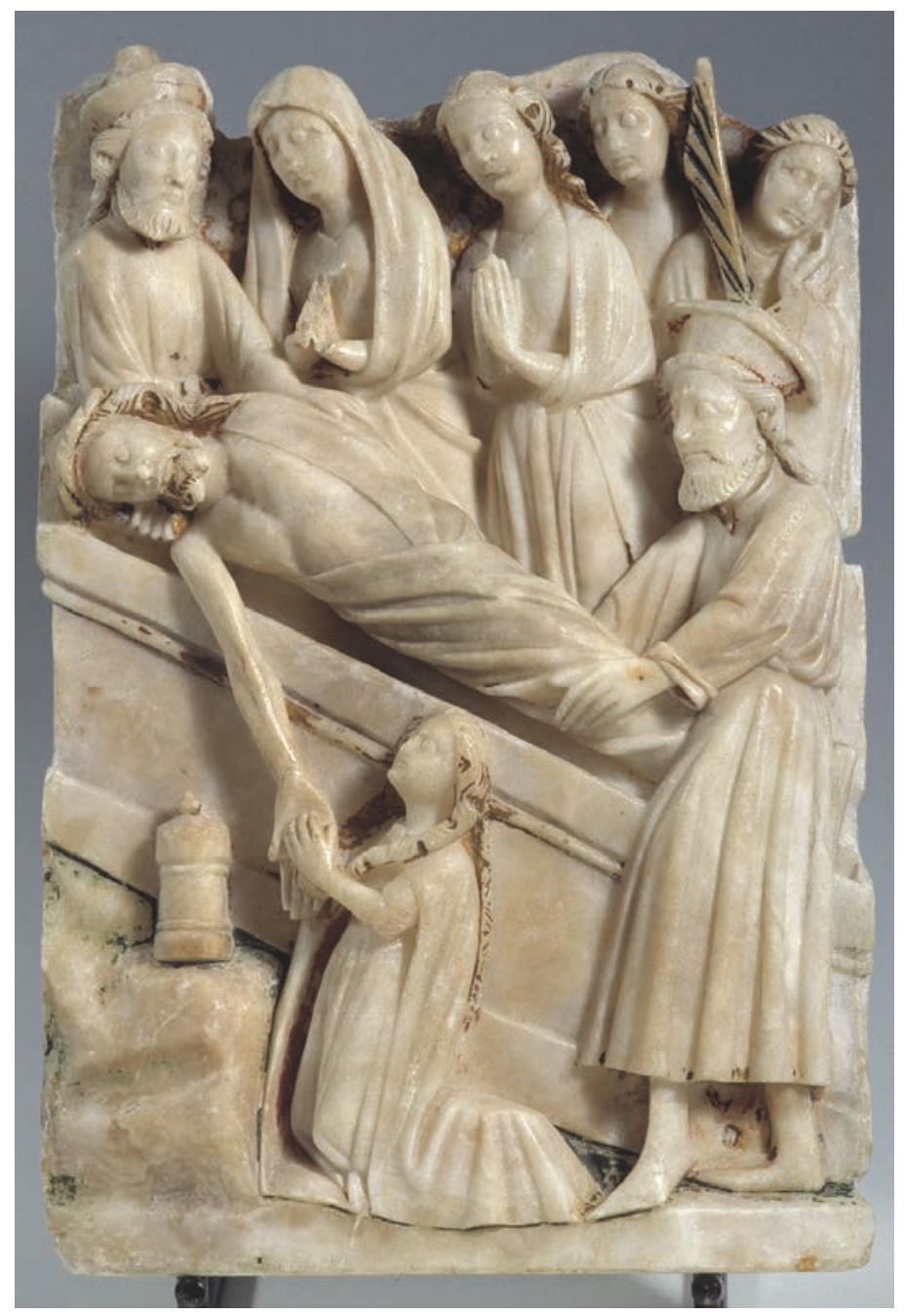

Fig. 7: Christ's Resurrection; Treviso, Museo Diocesano di Arte Sacra

dedicated to the Virgin in the Abbey Church of Novalesa ${ }^{58}$. Archival records attest that the chapel was founded in the second half of the fifteenth century by the mandatory Abbot Giorgio Provana ${ }^{59}$, who most likely provided the altar with all the required furnishings and wanted the chapel to be decorated with a painted cycle devoted to the Virgin Mary, done by Antoine de Lonhy ${ }^{60}$. The alabaster altarpiece must have integrated itself visually and iconographically within the paintings, since it also represents scenes from the life of the Virgin Mary. The altarpiece was removed and scattered after the Napoleonic suppressions. In 1875, one of its panels was published: the Coronation of the Virgin, now kept at the Museo di Palazzo Madama in Turin ${ }^{61}$, in those days in the private collection of Felice Chiapusso in Susa ${ }^{62}$. It was Felice Chiapusso himself who confirmed that the panel was given as a gift some forty years before by the monks of the Novalesa

${ }_{5^{8}}$ The record reads: 'Nell'altare e capella della Madonna, l'ancona d'allabastro di diverse figure'; Archivio di Stato di Torino (henceforth cited as ASTo), Sezioni Riunite, R. Economato dei Benefici Vacanti, Abbazia della Novalesa, mazzo I. The inventory is transcribed in G. GENTILE, Antichi arredi alla Novalesa, in Nuove scoperte alla Novalesa. Raccolta di studi presentati al convegno per il 125oesimo dell'atto di donazione di Abbone alla abbazia benedettina, in Segusium, 15, 1979, 15, pp. 81-110: 106-110.

59 The Liber cappellarum of 1644 mentions the 'Cappella Beate Marie fundata in Ecclesia Abbatiali Sancti Petri Novaliciensis a latere magni altaris a parte meridiei et fundata fuit per reverendum Dominum Georgium Provana priorem dicte Abbatie qui defunctus est anno 1502 die 14 Junii'. ASTo, Corte, Abbazia di Novalesa, mazzo 14. The document is transcribed in A. BO, Gli affreschi seicenteschi della chiesa dei SS. Pietro e Andrea dell'abbazia di Novalesa, in La Novalesa. Ricerche, fonti documentarie, restauri, Conference proceedings (Novalesa, 1981), Novalesa, 1988, pp. 235-239.

${ }^{60}$ A. GUERRINI, La chiesa abbaziale di Novalesa. Cantieri conclusi, cantieri aperti, "Bollettino d'arte", s. VI, LXXVIII, 1993, 8o-81, pp. 163-181.

${ }^{61}$ A. GUERRINI, in Tra Gotico e Rinascimento. Scultura in Piemonte, Exhibition catalogue (Turin, June-November 2001), ed. by E. Pagella, Turin, 2001, p. 122, n. 41.

${ }^{62}$ Cfr. C. F. BISCARRA, Di alcuni rari cimelii in Susa, in Atti della Società di Archeologia e Belle Arti per la Provincia di Torino, 1, 1875, pp. 183-192: 188-191, and tav. VIII. 


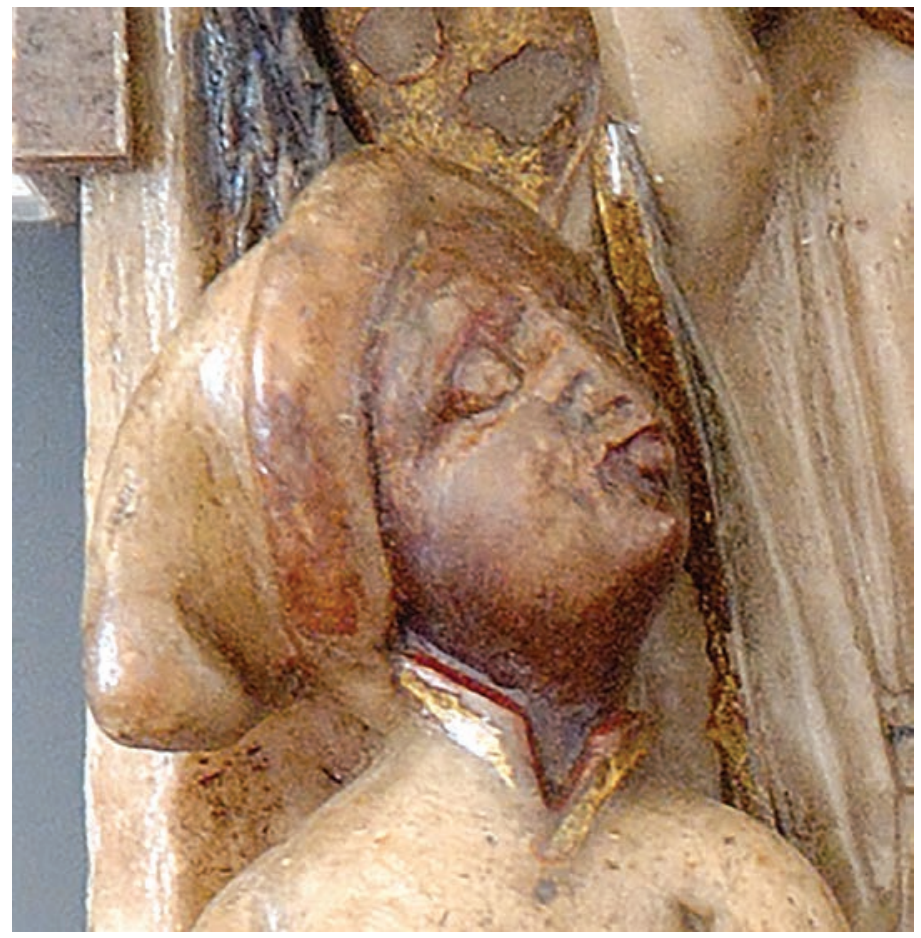

Fig. 8: Christ's Flagellation, detail; Venice, Pinacoteca Manfrediniana del Seminario Patriarcale

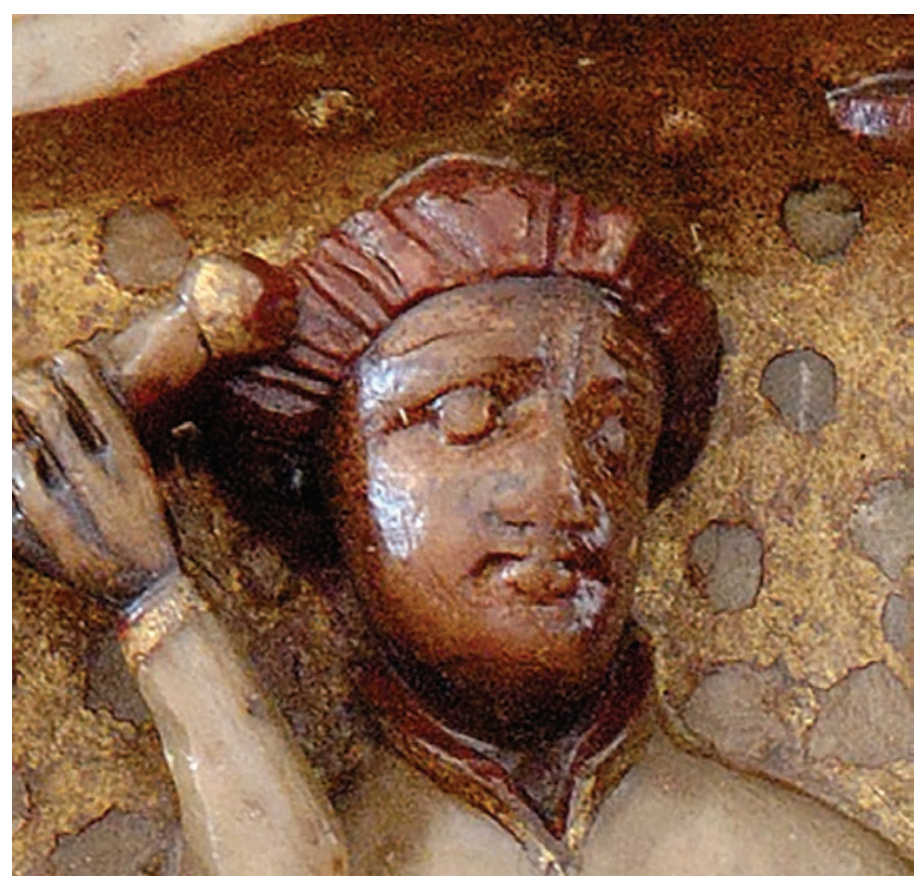

Fig. 10: Christ's Flagellation, detail; Venice, Pinacoteca Manfrediniana del Seminario Patriarcale

to a certain D. Gattiglio, parish priest of Ferrera, who later gave it to the Chiapusso family. A drawing of a Crucifixion was published together with the Coronation of the Virgin of Turin. The panel, which belonged to the same altarpiece, had been found within the ruins of a house destroyed by fire, located near the Novalesa abbey. That same carving, which

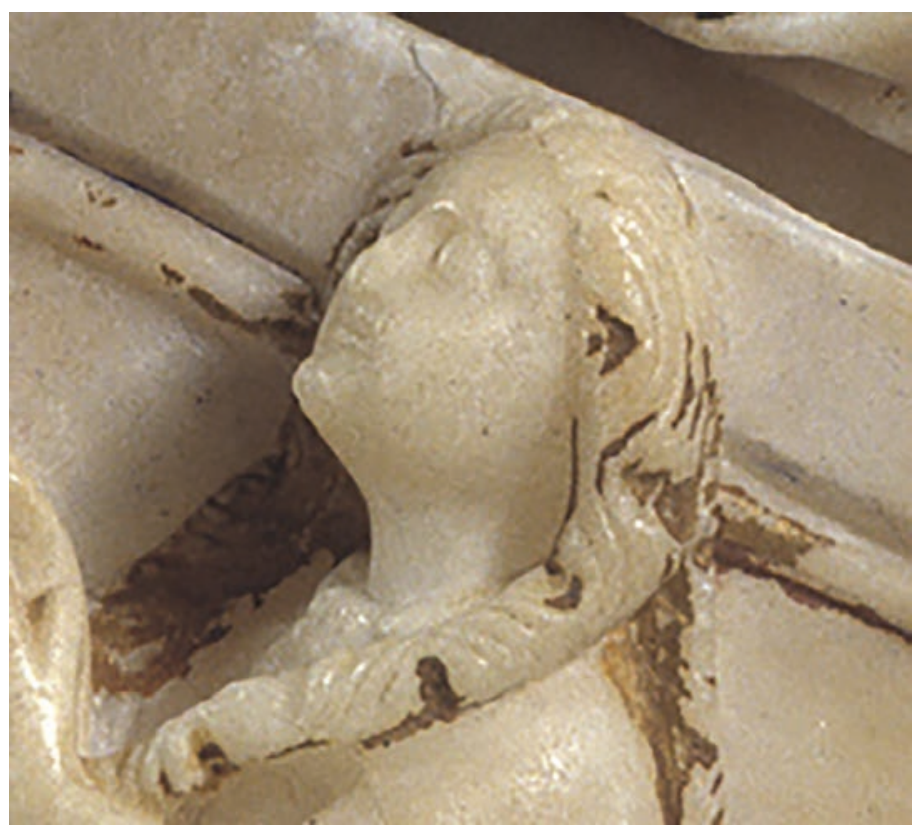

Fig. 9: Christ's Deposition, detail; Treviso, Museo Diocesano di Arte Sacra

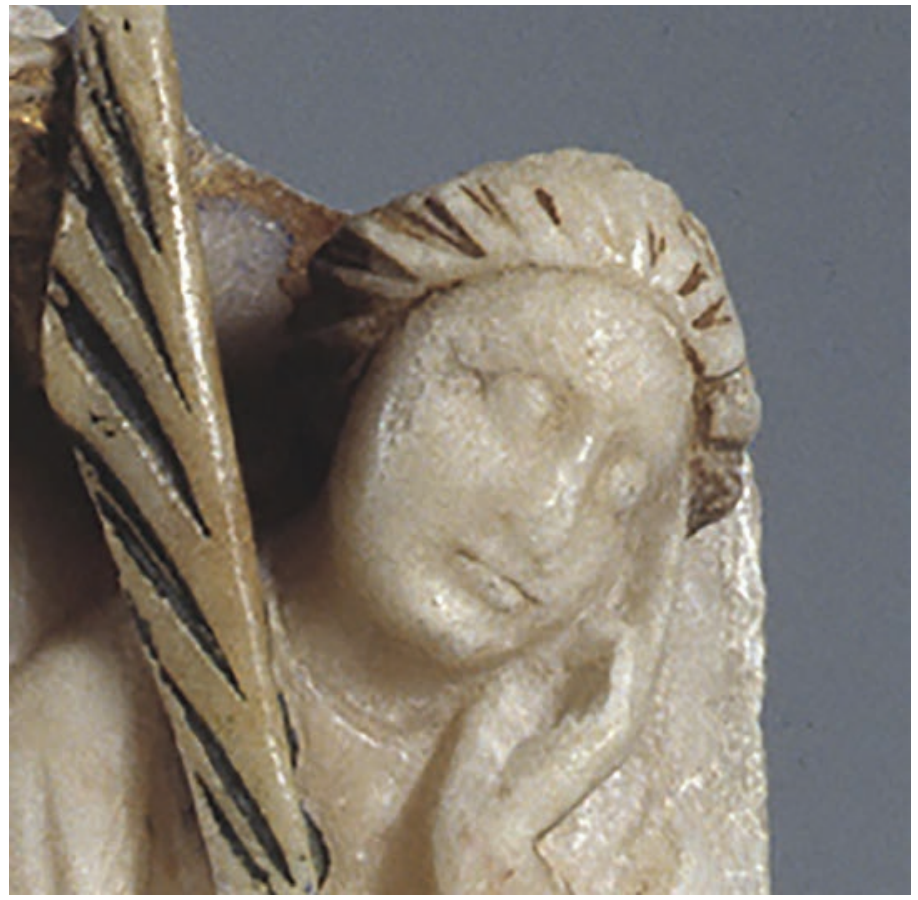

Fig. 11: Christ's Deposition, detail; Treviso, Museo Diocesano di Arte Sacra

got lost shortly after ${ }^{63}$, is also visible in a photo taken at the end of the nineteenth century. In the same circumstance, two other fragments were mentioned, originally part of an Adoration of the Magi, kept in a private collection ${ }^{64}$. I think also that the Assumption of the Virgin now on display at the Museo di Susa ${ }^{65}$ was part of the same altarpiece, since its style, dimensions, and format are consistent with those of the aforementioned pieces, as is its provenance from the same territory.

\footnotetext{
${ }_{6_{3}}$ I have recently been able to trace the carving in a private collection. I will discuss it in detail in an essay devoted to the Novalesa altarpiece, entitled Intercultural exchange between England and Italy: Alabaster Sculpture in Unexpected Quarters, in Artistic Exchange in Unexpected Quarters: Art, Travel and Geography during the Renaissance, ed. by J.W. Anderson, Turnhout, in press.

${ }_{4}^{6}$ Photos of the fragments are published in A. GUERRINI, op. cit. (n. 6o), p. 170, figs. 14-15.

${ }_{55}$ G. GENTILE, Immagini e apparati per il culto e la memoria nell'antica chiesa abbaziale, in Novalesa. Nuove luci dall'abbazia, ed. by M. G. Cerri, Milan, 2004, pp. 73-89: 82-83.
} 


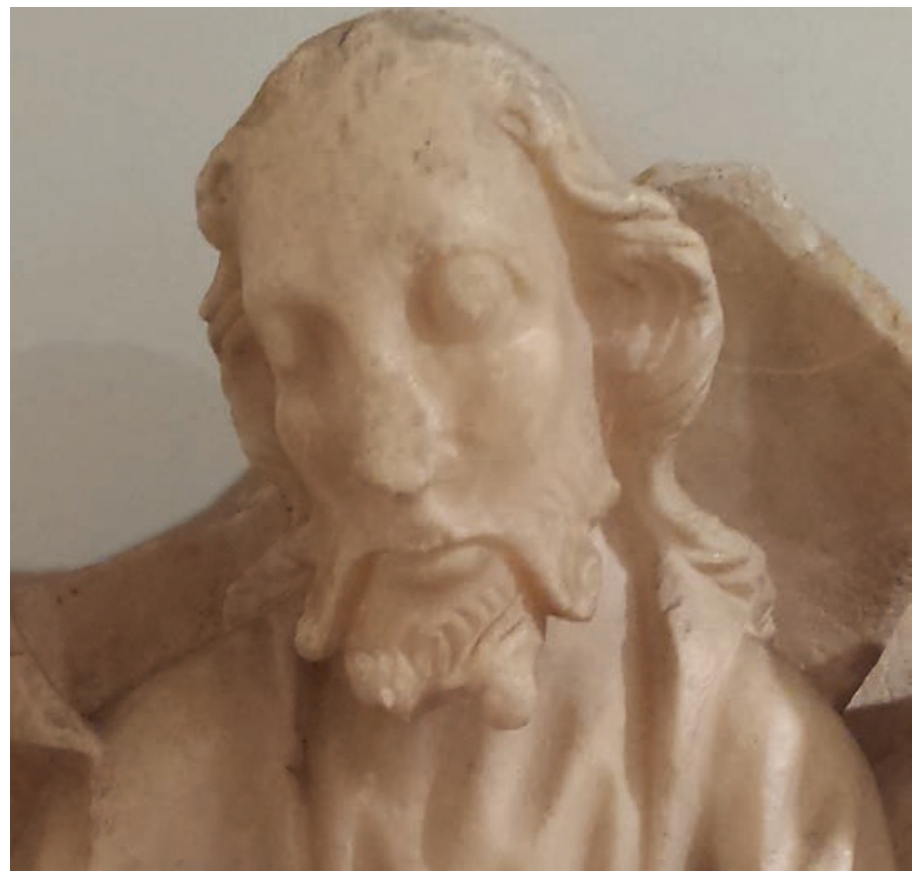

Fig. 12: The Last Supper, detail; Vicenza, Museo Diocesano

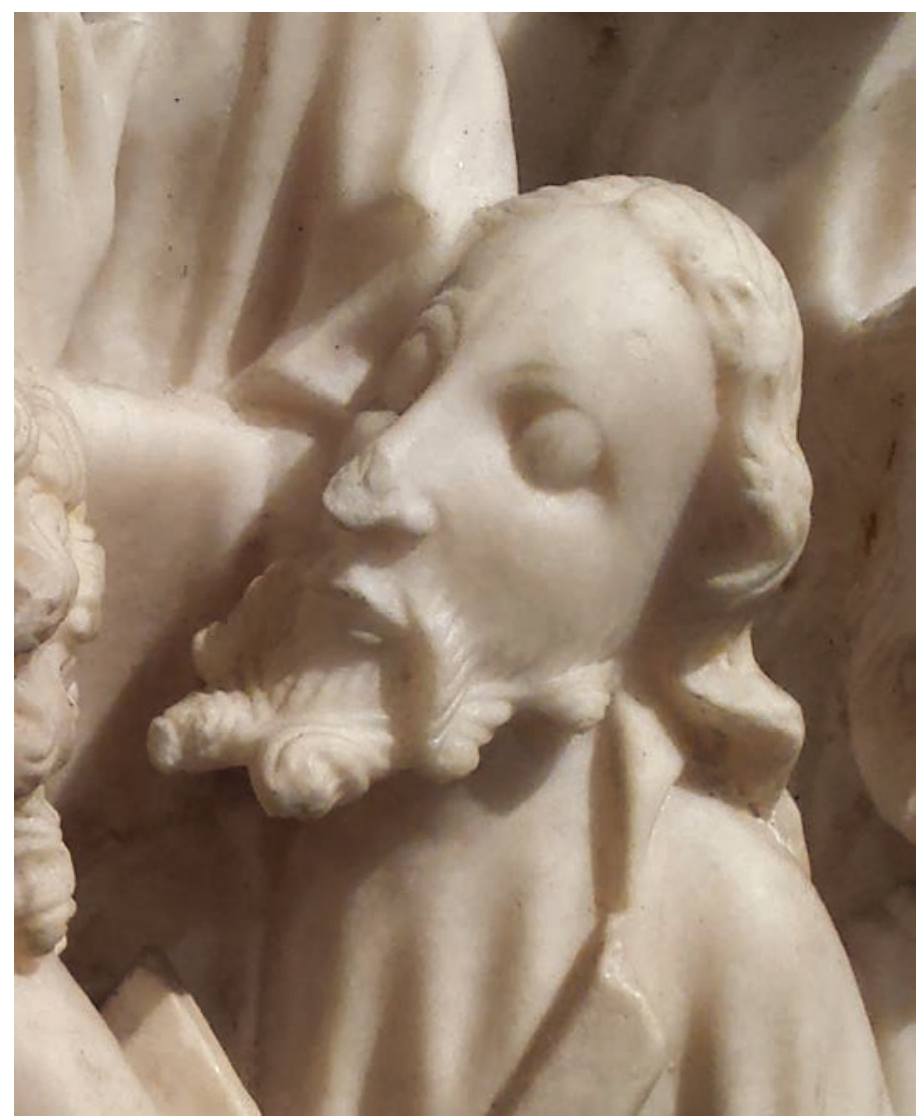

Fig. 14: The Pentecost, detail; Vicenza, Museo Diocesano

I would not exclude the possibility that also the pieces now at the Museo Diocesano in Vicenza ${ }^{66}$ and at the Pinacoteca del Seminario Vescovile in Rovigo ${ }^{67}$ belonged originally

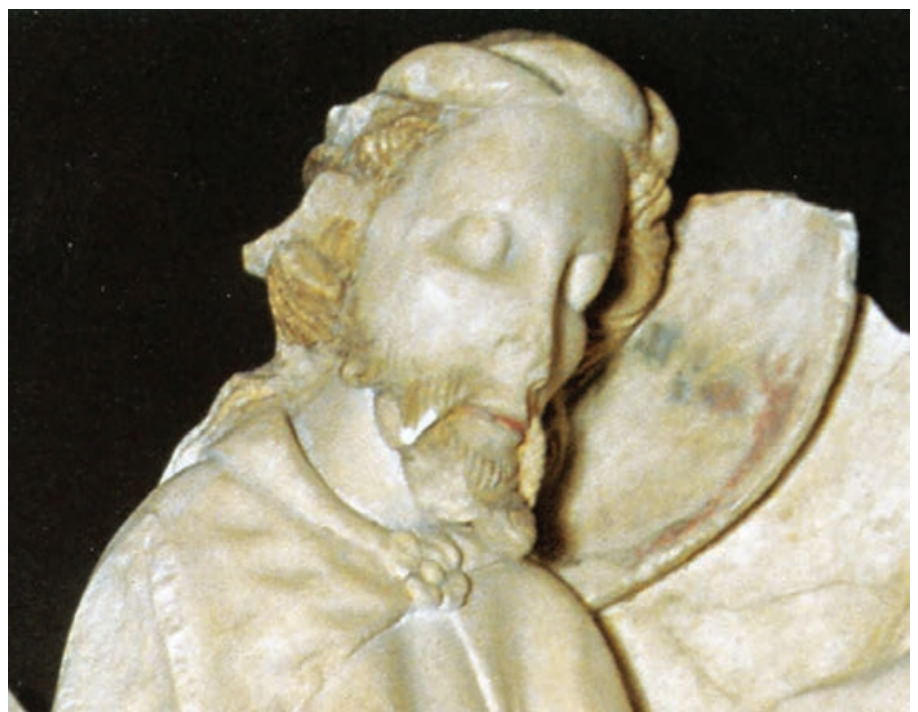

Fig. 13: Christ's descent into Limbo, detail; Rovigo, Pinacoteca del Seminario Vescovile

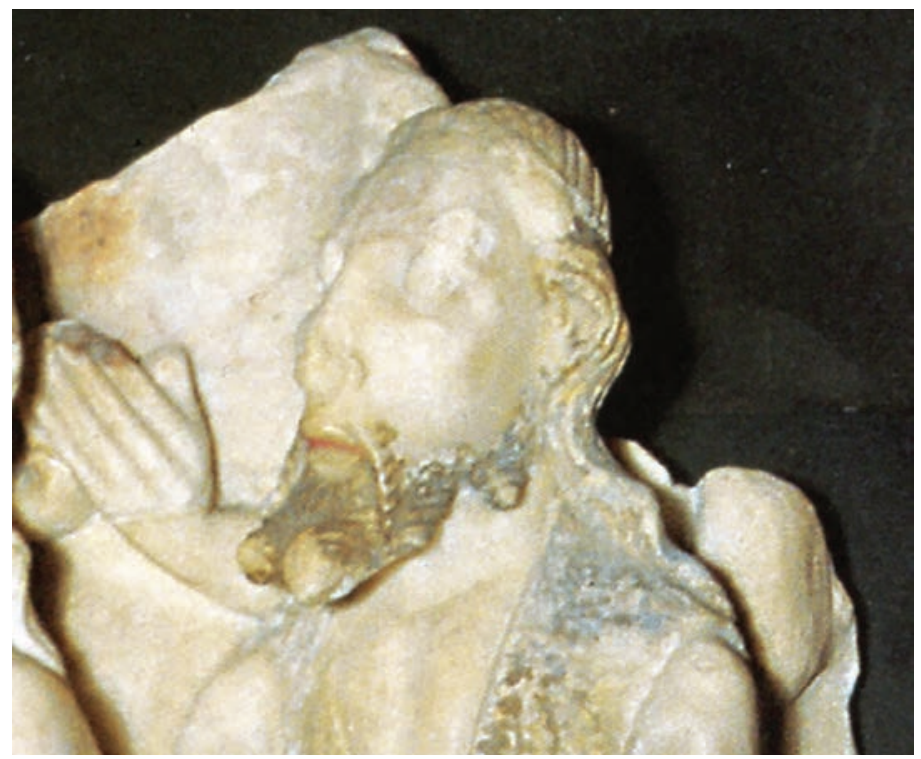

Fig. 15: Christ's descent into Limbo, detail; Rovigo, Pinacoteca del Seminario Vescovile

to the same altarpiece, as their similar style, typology, dimensions ${ }^{68}$ and iconography, plus their common provenance from the Veneto, seem to suggest. The pieces in Vicenza show the Last Supper, the Ascension of Christ and the Pentecost; the panel in Rovigo represents Christ descent into Limbo. From a stylistic point of view, the similarities between the faces are particularly remarkable (figs. 12-15): see the way in which the beards are carved, with curls in pairs along the chin and the jaw; and the hair, created by the superposition of several locks shapely arranged around the visages. The style is consistent with other carvings done at the beginning of the fifteenth century, such as St. John the Baptist in the Victoria and Albert Museum in London ${ }^{69}$, which implies an equivalence with the dating.

\footnotetext{
$\overline{{ }^{6}}$ On these artworks: D. SAMADELLI, in Historia Christi. Arte e fede nella chiesa vicentina, Exhibition catalogue (Vicenza, April-August 2008$)$, ed. by C. Rigoni, Crocetta del Montello, 2008, pp. 86-89, n. 26.

${ }^{67}$ D. SAMADELLI, in Splendori del Risorto. Arte e fede nelle chiese del Triveneto, Exhibition catalogue (Verona, October 2006-January 2007), ed. by A. M. Spiazzi, A. Nante, L. Andergassen, Cinisello Balsamo, 2006, pp. 68-69.

${ }^{68}$ All the pieces are now damaged, thus their dimensions are now slightly smaller than they used to be. The carvings in Vicenza measure $44 \times 30 \mathrm{~cm}($ Last Supper), 44 × $31 \mathrm{~cm}$ (Ascension), and 46 × $32 \mathrm{~cm}$ (Pentecost); the panel in Rovigo measures $42 \times 32 \mathrm{~cm}$.

${ }^{69}$ F. CHEETHAM, op. cit. (n. 4), p. 113, n. 42.
} 


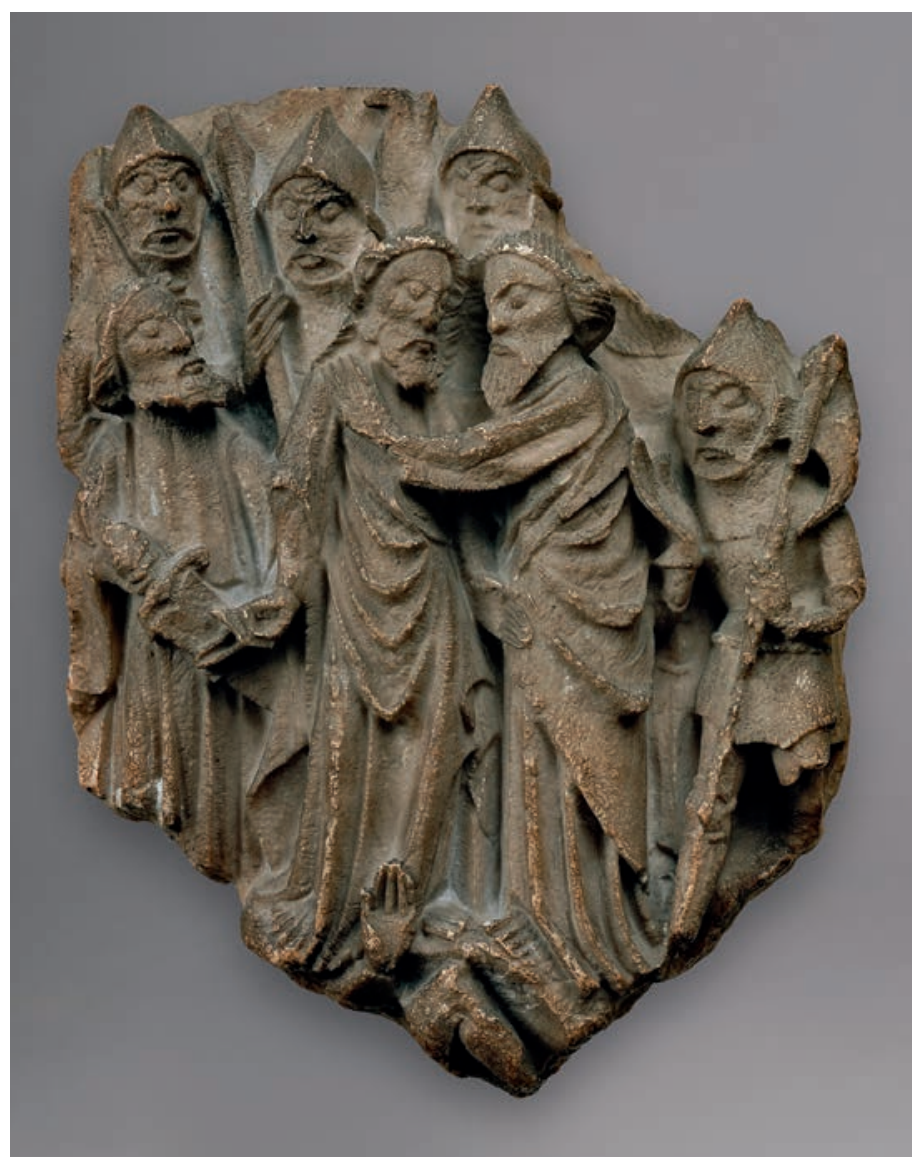

Fig. 16: The Betrayal of Christ; Milan, Museo d'Arte Antica del Castello Sforzesco

The Descent into Limbo of Rovigo belonged to the private collection of the Earl Camillo Silvestri (1645-1719), who during his lifetime had founded an outright museum transferred to the city after his death ${ }^{70}$. The main part of the artworks he collected came from the territory of Padua, Adria and Este ${ }^{71}$. The reliefs now in Vicenza were part of the rich donation that the Abbot Earl Ottavio Muttoni bequeathed to his diocese in $1873^{72}$. The member of a very wealthy family, Muttoni possessed an art collection he increased constantly with new acquisitions, often from the territory of Vicenza where he was very active ${ }^{73}$. Therefore, we might hypothesize that an alabaster altarpiece devoted to the Passion of Christ existed in a church between Padua and Vicenza. It might have been removed from its original location and the panels scattered at the beginning of the eighteenth century.

Similarly plausible is the provenance from the same altarpiece of some panels now kept in different collections in Milan, and in particular the Betrayal of Christ in the Museo d'Arte Antica del Castello Sforzesco (fig. 16) and the Deposition in the Pinacoteca di Brera ${ }^{74}$. These pieces are very damaged and fragmentary, and they have also completely lost their original polychromy. Thus, the analysis of their style is disrupted by the difficulties caused by their poor state of preservation. Yet, it is still possible to note the similarities in the treatment of the draperies: they are rigid, angular and pointy, built on the alternation of pronounced reliefs and deep wrinkles, that completely hide the anatomy of the bodies below them. More in particular, there is an identical detail in both the carvings, which is the way in which the sleeves of Judas and Joseph of Arimathea's dresses are arranged on the arms, creating a deep hollow at the centre, elevated where there is the limb and where the drape relapses down. Again, it is also possible to note many similarities in the way that faces, hair and beards are carved. These details are consistent with artworks carved in the first half of the fifteenth century, such as The Crucifixion and the Entry into Jerusalem of the Victoria and Albert Museum ${ }^{75}$. The Betrayal of Christ boasts a prestigious pedigree. Indeed, it comes from the now demolished Rocchetta Viscontea in Porta Romana in Milan, part of the Visconti palace, where it was likely set on the altar of the family's private chapel. It was evidently part of an altarpiece devoted to the Passion of Christ. In 1793, when the Austrians destroyed the Rocchetta, the altarpiece was removed and scattered in pieces to be sold separately. The frequent relations between Milan and England, strengthened further thanks to the weddings between members of the Visconti family and the English Royal House and nobility ${ }^{76}$, provide an historical context for the existence of well established cultural and artistic relationships.

The diffusion of that kind of artwork in the context of Italian courts provides us with sufficient evidence of the high

$77^{\circ}$ B. GAMBA, Galleria dei Letterati ed Artisti Illustri delle Provincie Veneziane nel secolo Decimottavo, Venice, 1824, 2 vols., II; E. ZERBINATI, Il museo rodigino dei Silvestri in una raccolta di disegni inerenti del Settecento, Rovigo, 1982. The alabaster panel is among the artworks listed and drawn in the Museum Silvestrium Rhodiginum delineatum et illustratum, a manuscript of drawings that belongs to the Biblioteca Silvestriana, the private library of the Silvestri, now kept at the Accademia dei Concordi: Museum Silvestrium Rhodiginum delineatum et illustratum, Biblioteca Silvestriana presso l'Accademia dei Concordi di Rovigo, ms. 229, 18th century, p. 100, n. 162.

${ }^{71}$ G. P. TABONE, I bronzetti a figura umana etruschi e italici a Nord del Po. Diffusione di modelli ed elaborazioni locali in età arcaica, PhD Dissertation, Università degli Studi di Roma "La Sapienza", rel. prof. G. Colonna, 1995-1996, p. 35.

${ }^{72}$ Cfr. Legato Muttoni, Statuto organico, Vicenza, 1889; G. MANTESE, II legato Muttoni e una bonifica nel Polesine: la tenuta Moceniga in Rosolina, in Movimenti politici e sociali nel Veneto dal 1876 al 1903, Conference proceedings (Vicenza, November 1983), ed. by G. A. Cisorro, Vicenza, 1986, pp. 181-191.

73 Almanacco Ecclesiastico della Diocesi vicentina per l'anno 1842, Vicenza, 1842, p. 7.

${ }^{74}$ The Betrayal of Christ entered the Museum in 1888, gifted by Luca Beltramini; it was formerly in the collection of the Museo Settala (F. TASSO, in Maestri della scultura in legno nel ducato degli Sforza, Exhibition catalogue (Milan, October 2005-January 2006), ed. by G. Romano, C. Salsi, Cinisello Balsamo, 2005, pp. 88-89, n. I.16; L. PALOZZI, in Museo d'Arte Antica del Castello Sforzesco. Scultura lapidea. Tomo secondo, ed. by M.T. Fiorio, Verona, 2013, pp. 130-132, n. 538). The Deposition was formerly in the collection of Lamberto Vitali, and entered Brera in 2002 (Brera. Un milanese che parlava toscano. Lamberto Vitali e la sua collezione, Exhibition catalogue (Milan, June-December 2001), ed. by the Direzione della Pinacoteca di Brera, Milan, 2001, p. 90, n. 53; F. TASSO, in Maestri della scultura in legno nel ducato degli Sforza, Exhibition catalogue (Milan, October 2005 - January 2006), ed. by G. Romano, C. Salsi, Cinisello Balsamo, 2005, pp. 90-91, n. I.17).

75 F. CHEETHAM, op. cit. (n. 4), p. 221, n. 148; p. 253, n. 180.

${ }^{76}$ In 1368 Violante Visconti, daughter of Galeazzo II, married Lionel of Antwerp, first Duke of Clarence; in 1424 Lucia Visconti, daughter of Gian Galeazzo, married Edmund Holland, fourth Duke of Kent (S. B. TOSATTI, s.v. Visconti, in Enciclopedia dell'Arte Medievale, XI, Rome, 2000, pp. 68o-688). In 1337 Donnina Visconti, the illegitimate daughter of Bernabò, wed the English mercenary John Hawkwood (W. CAFERRO, John Hawkwood:An English Mercenary in Fourteenth-Century Italy, Baltimore, 2006). 


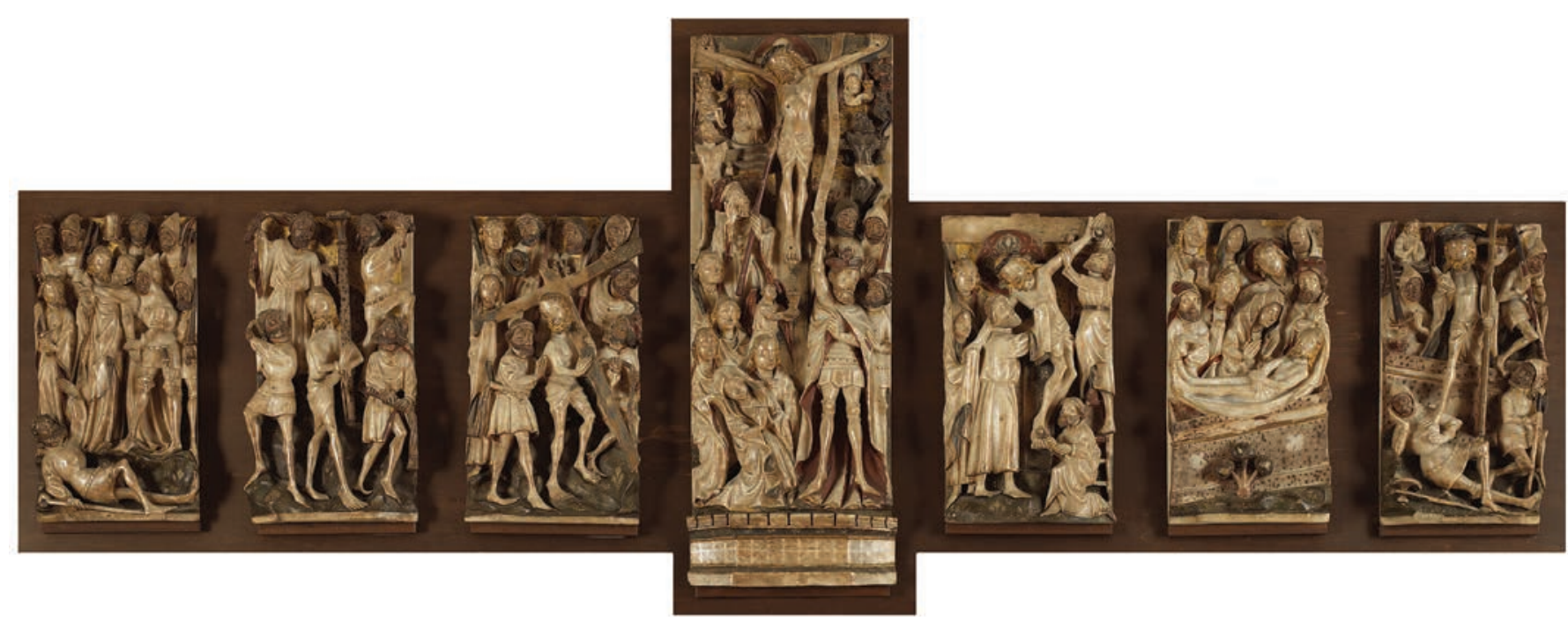

Fig. 17: Polyptych with the Passion of Christ; Ferrara, Museo Civico di Palazzo Schifanoia

value they were granted within that period. In addition to the polyptych in Milan, we shall also mention the one now kept at the Museo Civico di Palazzo Schifanoia in Ferrara (fig. 17), a huge altarpiece that consists of seven panels devoted to the Passion of Christ ${ }^{77}$. Before entering the museum, the polyptych used to be in the sacristy of the church of Sant'Andrea also in Ferrara ${ }^{78}$. According to a local tradition, however, it was originally 'the altarpiece of the domestic altar of the Estensi marquis, rulers of Ferrara'79, which is to say that it was the altarpiece of the palatine chapel of the Este family, inside their castle in the city centre of Ferrara. The alabaster polyptych might have been given as a gift by one of the British ambassadors who were invited to Ferrara during the reign of Borso d'Este $(1413-1471)^{80}$. The style of the carvings is indeed consistent with other artworks done around the mid-fifteenth century. The relocation of the polyptych in the church of Sant'Andrea might have taken place along with the construction of the new palatine chapel, begun in 1590. The destination of the altarpiece to the church of Sant'Andrea testifies to the high value it was granted. Indeed, the Augustinian church was one of the most important sacred buildings in Ferrara, and the Este were particularly keen in enriching it with frequent and abundant bequests ${ }^{81}$.

Also the triptych with scenes of the Passion of Christ now on display at the Museo di Capodimonte in Naples appears to have a noble lineage. Until 1799 it was in the sacristy of the church of San Giovanni a Carbonara. According to the canon Celano, the alabaster polyptych belonged to King Ladislao, buried inside that church ${ }^{82}$, who 'took it wherever he goes, even in battlefields, to put it on the altars when he wanted a mass to be celebrated ${ }^{83}$. However, Ladislao died in 1414, a date that is not consistent with the style of the altarpiece, to be set around 145o. Furthermore, the triptych can never have been a portable liturgical object, considering its dimensions and weight ${ }^{84}$. The connection between the triptych and Ladislao might have been suggested by the fact that it was Ladislao who promoted the enlargement of the church of San Giovanni a Carbonara, where the alabaster altarpiece might have arrived after Ladislao's death, thanks to the frequent trade between Naples and other European ports.

The prestige of this artwork can explain another presence in Campania, the triptych of the Museo della Collegiata di Santa Maria a Mare Don Clemente Confalone, formerly in the church of Santa Maria at Maiori ${ }^{85}$. Consistent with the dedication of the church, the triptych shows episodes from the Life of Mary in four panels. The central panel shows Christ's resurrection, while St. Margaret and St. James are standing to the sides. The carpentry is the original one and is still enriched with the inscriptions in Gothic characters and with the iron hinges used to close the lateral wings ${ }^{86}$. The altarpiece can be set around the mid-fifteenth century, which is to say more or less the same chronology of the

77 R. VARESE, Un polittico inglese in alabastro, in Il Museo Civico in Ferrara: donazioni e restauri, Exhibition catalogue (Ferrara, April-July 1985), Florence, 1985, pp. 124-128, cat. 4; G. SASSU, in Cosmè Tura e Francesco del Cossa. L'arte a Ferrara nell'età di Borso d'Este, Exhibition catalogue (Ferrara, September 2007-January 2008), ed. by M. Natale, Ferrara, 2007, pp. 238-239, n. 36.

${ }^{78}$ G.A. SCALABRINI, Memorie istoriche delle Chiese di Ferrara e de' suoi borghi, Ferrara, 1773, p. 306; A. FRIZZI, Guida del Forastiere per la città di Ferrara, Ferrara, 1787, p. 129.

${ }^{79}$ Ibidem.

${ }^{80}$ R. VARESE, Un polittico inglese in alabastro, in Il Museo Civico in Ferrara, op. cit. (n. 77), pp. 124-128, n. 4.

${ }^{81}$ G. MEDRI, Chiese di Ferrara nella cerchia antica, Bologna, 1967, pp. 231-235; T. TUOHY, Herculean Ferrara. Ercole d'Este (1471-1505) and the invention of a ducal capital, Cambridge, 1996, pp. 367-368.".

${ }^{82}$ On King Ladislao's tomb: G. DONATI, Andrea di Francesco Guardi: uno scultore di costa nell'Italia del Quattrocento, Pisa, 2015.

${ }_{3}$ C. CELANO, Notitie del bello, dell'antico e del curioso della città di Napoli per i signori forastieri date dal canonico Carlo Celano napoletano, divise in dieci giornate, Naples, 1692.

${ }^{84}$ The triptych measures $165 \times 306 \mathrm{~cm}$ and weighs $230 \mathrm{~kg}$; cfr. P. GIUSTI, in Restituzioni 2013. Tesori d'arte restaurati - catalogo digitale delle opere, Exhibition catalogue (Naples, March-July 2013), ed. by C. Bertelli, G. Bonsanti, Venezia, 2013, pp. 184-194, n. 23 [available online: http://restituzioni.marsilioeditori. it/2013/, last visited on 12 January 2016].

${ }^{85}$ Sculture lignee nella Campania, Exhibition catalogue (Naples, 1950), ed. by F. Bologna, R. Causa, preface by B. Molajoli, Naples, 1950, pp. 123-125, n. 43; G. BENINCASA, op. cit. (n. 9); A. PARLATO, Il Paliotto in alabastro inglese della Collegiata di Maiori, in Il Vescovado. Il giornale di Ravello e Costa d'Amalfi, [available online: http://www.ilvescovado.it/it/sezioni-25/storia-e-storie-12/il-paliotto-in-alabastro-inglese-della-collegiata-8584, last visited on 2 January 2016]. ${ }^{86}$ The inscriptions read: S(ancta) Margareta, Salutatio S(anct)e Marie, Nativitatis D(omini)ni N(ost)ri, Resurrectio D(omini)ni N(ost)ri, Assumptio S(anct)e Marie, S(anctus) Jacob(us). 


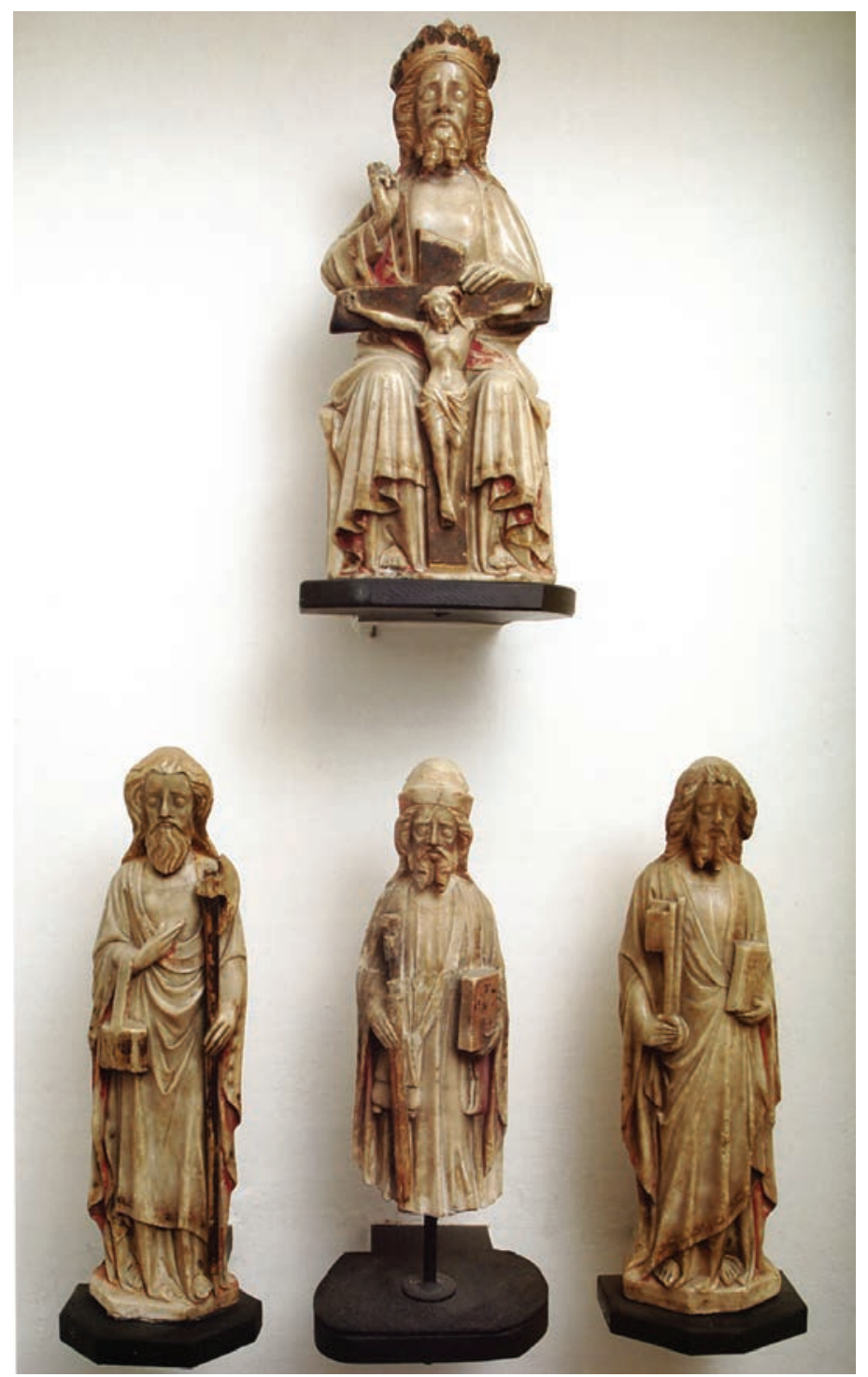

Fig. 18: The Trinity; The Apostles Mathias, James the Great and Peter; Savona, Museo del Tesoro della Cattedrale

Naples triptych. The pastoral visits of 1576, 1608 and 1639, described it as a 'portable marble altarpiece' kept in the chapel of St. Vincent, from where it was likely moved to be placed on the main altar during specific ceremonies of the liturgical year ${ }^{87}$. In 1671 , again in a pastoral visit, it is described as a 'painted altar-frontal in seven panels'; at that point, it was held in the sacristy ${ }^{88}$. It was still in that same position in 1853 , when Luigi Staibano saw and described $\mathrm{it}^{89}$, while in 1865 it was stored behind the main altar ${ }^{90}$.

We do not know when the altarpiece reached the Amalfi coast and the church of Maiori. The relationships and trades

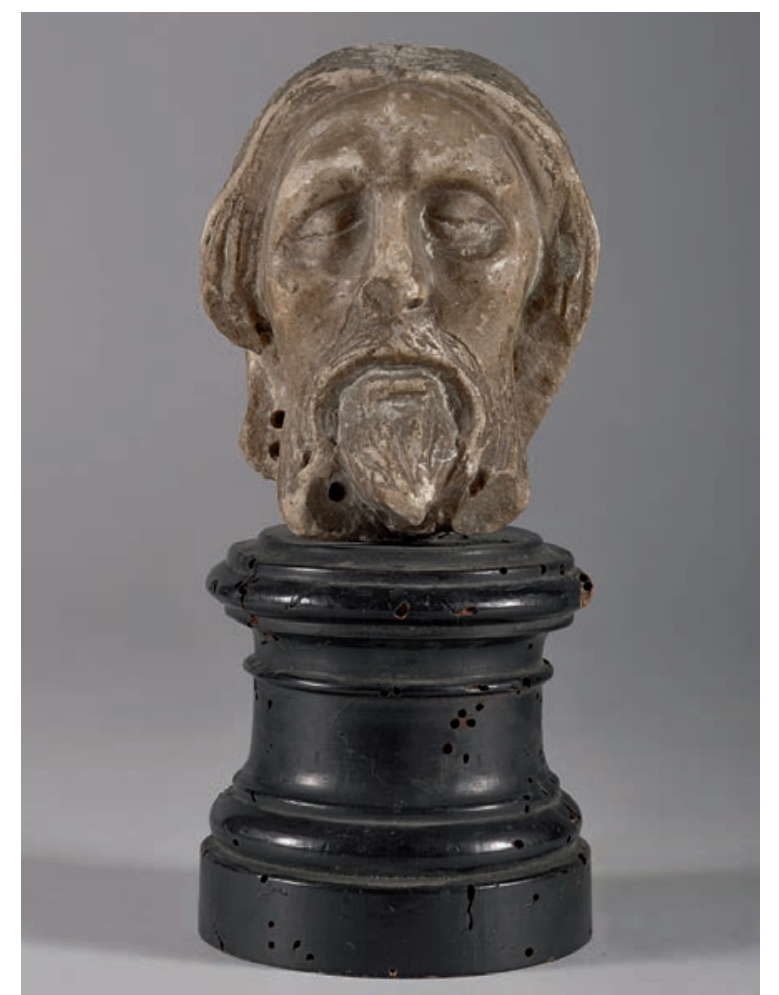

Fig. 19: Male Head (an Apostle?); Milan, Museo d'Arte Antica del Castello Sforzesco (depot)

between Campania and Northern Europe were facilitated by the region's access to the sea. Indeed, the geographical distribution of the alabaster artworks in the Italian peninsula is not accidental at all. On the contrary, it is consistently massed along the coastal strips or in areas near important commercial port terminals. In this respect, and in addition to the aforementioned artworks kept in Venice and in the Campania region, we shall also think of the numerous carvings held in Liguria and Trieste. I am here thinking of the sculptures of the Museo del Tesoro della Cattedrale in Savona, with a Trinity and the Apostles Mathias, James the Great and Peter (fig. 18). They are recorded in the Cathedral by the mid-nineteenth century, when they were placed in the sacristy ${ }^{91}$. They might have been originally destined to the ancient cathedral of Santa Maria Assunta, destroyed by the army of Genoa in 1542, when they might have been moved to the new location ${ }^{22}$. As an alternative, according to some scholars, the carvings might have been held originally in the church of San Francesco, where they might have formed part of the furnishings of the chapel of the Cerrato, a noble family that traded all over Europe and also in England ${ }^{93}$.

I would not exclude that the Male head (fig. 19) now in the depot of the Museo d'Arte Antica del Castello Sforzesco

\footnotetext{
$\overline{8_{7}}$ The aforementioned pastoral visits are held in the Archivio della Curia della Diocesi di Amalfi (henceforth cited as ACDAm): Fascicolo VI, libro I, p. 10; Fascicolo VIII, libro V, pp. 36-40. Cfr. A. PARLATO, op. cit. (n. 85).

${ }^{88}$ ACDAm, Fascicolo XIV.2, libro IX, p. 20. Cfr. Cfr. A. PARLATO, op. cit. (n. 85).

${ }^{89}$ L. STAIBANO, Raccolta di memorie storiche per Maiori, ms., Napoli, Biblioteca della Società di Storia Patria, ms. 1853 , p. 67.

${ }_{90}^{\circ}$ F. CERASUOLI, Scrutazioni storiche, archeologiche, topografiche con annotazioni e documenti sulla città di Majori, Salerno, 1865, p. 78. Cfr. also M. CAMERA, Memorie storico-diplomatiche dell'antica città e ducato di Amalfi, Salerno, 1876, vol. I, p. 84.

${ }_{91}$ T. TORTEROLI, Monumenti di pittura, scultura e architettura della città di Savona, Savona, 1847, p. 212; F. ALIZERI, Notizie dei professori del disegno in Liguria dalle origini al secolo XVI, IV, Scultura, Genoa, 1877, p. 55.

${ }_{92}$ G. ALGERI, C. VARALDO, Il Museo della Cattedrale di Santa Maria Assunta a Savona, Savona, 1982, pp. 40-41; C. VARALDO, La Cattedrale sul Priamàr, un monumento perduto, in Un'isola di devozione a Savona. Il complesso monumentale della Cattedrale dell'Assunta. Duomo, Cappella Sistina, Palazzo Vescovile, Oratorio di N.S. di Castello, Savona, 2002, pp. 21-56.

${ }_{93}$ M. BARTOLETTI, Appunti sulla situazione figurativa tra Savona, il Finale e l'alta Val Bormida nell'età di Macrino, in Intorno a Macrino d'Alba. Aspetti e problemi di cultura figurativa del Rinascimento in Piemonte, Conference proceedings (Alba, 2001), ed. by F. Cervini, E. Torchio, Savigliano, 2002, pp. 55-56.
} 
in Milan, whose provenance is unknown, belongs to the same complex. The carving is $12 \mathrm{~cm}$ high, a dimension that corresponds precisely to that of the heads of the Apostles in Savona, whose full-length is approximately $40 \mathrm{~cm}$ high. The sculpture entered the Museum between the end of the nineteenth and the beginning of the twentieth century. If we credit this hypothesis, we might think that it was separated from the other carvings and entered the art market because, being it fragmentary, it was not of interest for the canons as a liturgical furnishing. After all, even the sculptures in Savona were probably separated one from the others for a certain period, a circumstance that is consistent with the hypothesis of a different and independent sequence of events. Indeed, Torteroli in 1847 saw in the sacristy of the Cathedral of Savona only 'Three fine sculptures'; he also specified that they represented 'The Trinity and two Apostles'. At that time, therefore, one of the Apostles that now form the group was kept elsewhere in the church. With prophetic intuition Torteroli also added that 'I wish the Opera won't let them there, unstable and subject to be broken'94.

The stylistic interpretation of the Male head now in Milan is far from being effortless, due to its poor state of preservation. Yet, the quality of the carving seems to be similar to the statues in Savona, with particular respect to the thinned shape of the faces, with the prominent eyes, and the thick beards with wavy strands. All these artworks must be considered early products of the school of Nottingham, to be set at the end of the Trecento or at the beginning of the Quattrocento. From a typological and functional point of view, these carvings are of the greatest interest. Indeed, it is the only set of a so called 'Apostles' Creed Altarpiece' that still preserves its central figure, the Trinity, and that could thus enable understanding of what the original structure of this kind of altarpiece might have looked like, and how it was arranged on the altar, an investigation that in this particular case would take advantage of the known provenance of the artwork from Savona ${ }^{95}$.

Another four panels are kept in Liguria, in the Museo di Sant'Agostino in Genoa. They are a carving with Mary of Mercy, and then a Trinity that must have been flanked by two other panels with Saints and Prophets with Patriarchs. The latter three might have composed an altarpiece of the Te Deum type, meant to show the Trinitarian dogma through the integrality between the Ancient and the New Law ${ }^{96}$. Three carvings now at the Victoria and Albert Museum in London also come from Genoa. They were given as a gift to the museum in 1946 by W. L. Hildburgh. They represent three scenes of the Life of St. John the Baptist. Although their original provenance is not documented ${ }^{97}$, according to some scholars they might have formed part of the liturgical furnishing of the Cathedral of Genoa, where some important relics of John the Baptist were kept, being highly venerated ${ }^{98}$.

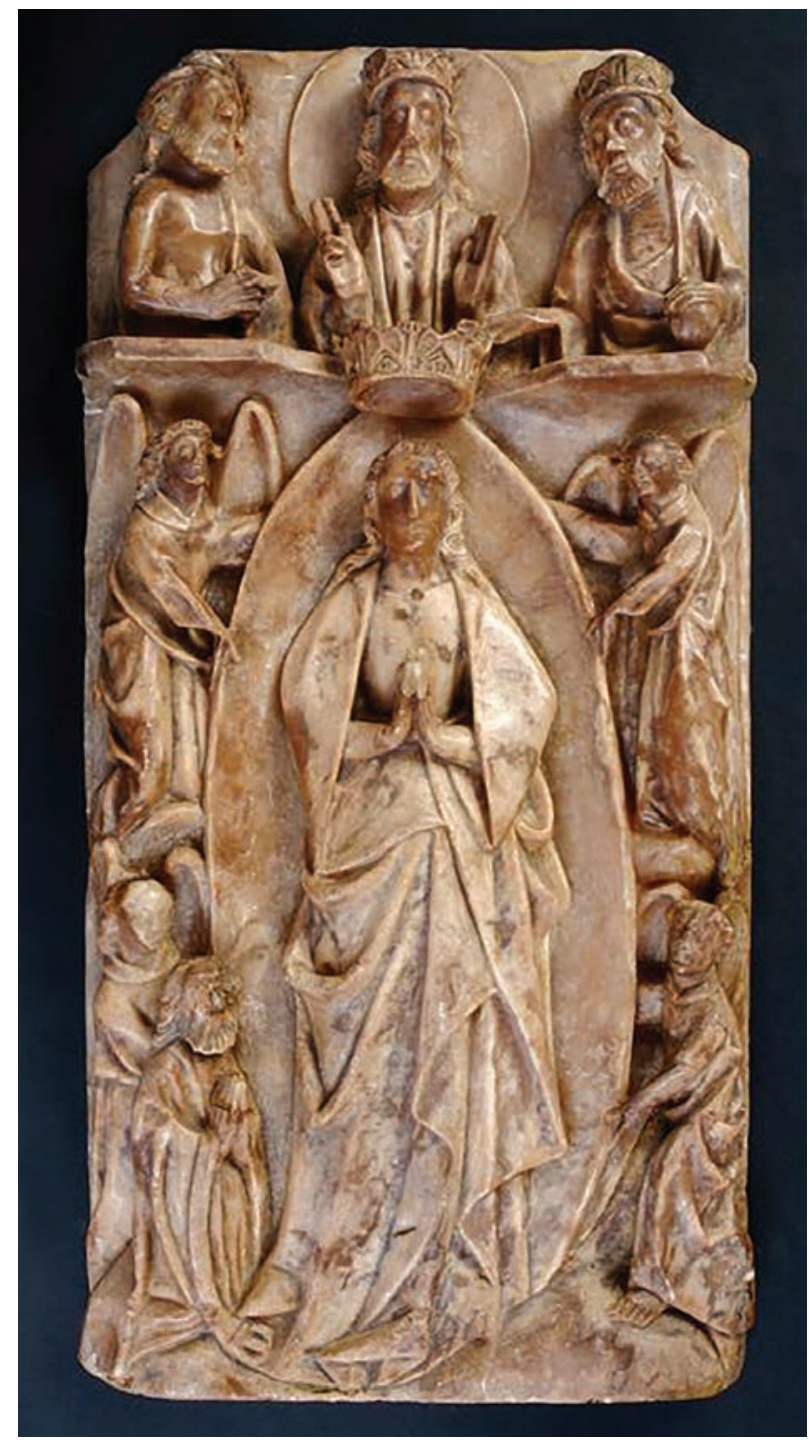

Fig. 20: The Assumption of the Virgin; Trieste, Museo Civico di Storia e Arte

The Museo Civico di Storia e Arte of Trieste keeps two different series of alabasters, that represent Scenes of the Life of Christ and of the Life of St. Catherine respectively. To the latter another independent panel has thus far been mistakenly connected. It shows the Assumption of the Virgin Mary (fig. 20), erroneously interpreted as a depiction of St. Catherine in Glory ${ }^{99}$. A comparison with other artworks that show the same episode, with the Virgin crowned by the Trinity, the angels that are raising the mandorla, St. Thomas who is receiving the Virgin's belt, leaves no doubt on the identification. We shall thus suppose that a third altarpiece did exist in Trieste, and that it represented the Joys of the Virgin.

The first group appears to be an early product, created at the very beginning of the Quattrocento or maybe already at the end of the Trecento, as the essentiality of the composition, extremely elegant, and the squared shape of the

\footnotetext{
${ }_{94}$ T. TORTEROLI, op. cit. (n. 91).

${ }_{95}$ The only complete series of twelve Apostles from an Apostles' Creed Altarpiece, yet lacking its central figure, is kept at the Victoria and Albert Museum in London. It likely comes from a Spanish church. P. NELSON, Some Unpublished English Medieval Alabaster Carvings, in Archaeological Journal, 77, 1920, pp. 213-225; F. CHEETHAM, op. cit. (n. 4), p. 69, n. C.

${ }_{96}^{6}$ On these sculptures: Museo di Sant'Agostino, ed. by I.M. Botto, Genoa, 1984, pp. 139, 142; F. CERVINI, op. cit. (n. 8), pp. 51-52; ID., op. cit. (n. 8), p. 52. ${ }_{97}^{97}$ F. CERVINI, op. cit. (n. 8), p. 53; ID., op. cit. (n. 8), p. 52.

${ }_{98}^{8}$ P. NELSON, Some Underscribed English Alabaster Carvings, Archaeological Journal, 82, 1925, pp. 25-38.

${ }_{99}$ M. B. FIORIN, Due serie di bassorilievi alabastrini al Museo Civico di Storia e Arte di Trieste, in Atti dei Civici Musei di Storia ed Arte di Trieste, 1969-1970, pp. 137-165: 140 .
} 
panels demonstrate. The episodes are set against ideal rooms where a drapery is open, allowing the viewer to see what is happening inside the houses. Small cylinders are placed on both sides of the upper frame and seem to simulate an accessible battlement. These carvings were donated to the municipality in 1807 by Giuseppe Nigris, city chancellor. Carlo Kunz, who published them in the first catalogue of the museum, stated that they came from a suppressed church of Trieste, without providing any further details ${ }^{100}$.

The second group, with Scenes of the life of St. Catherine, belongs to a later period, as is demonstrated by the drapery, angled and rigid, and superabundant, that can be compared to artworks as the Martyrdom of St. Catherine of the Victoria and Albert Museum ${ }^{101}$. Finally, the panel with the Assumption of the Virgin, with its dresses abundantly hanging down on the ground with soft folds, shows to have been done at the beginning of the Quattrocento.

Referring to the three panels with the Life of St. Catherine (mistakenly interpreted as the Life of St. Barbara) and the one with the Assumption of Mary, Kunz stated that 'According to an accredited tradition, they were linked to an altar that belonged to the confraternity of the bombers, in the suppressed church of the Madonna del Mare ${ }^{102}$. However, the confraternity of the bombers did not have its site in the church of the Madonna del Mare, but in that of Santi Sebastiano e Rocco instead, where an altar devoted to St. Barbara-patron saint of the brotherhood-used to be and was managed by the confraternity. We might hypothesize that the confraternity was happy with the iconography of the altarpiece because of the episode of the Burning of the philosophers. Furthermore, Catherine and Barbara shared a similar faith ${ }^{103}$, and one might wonder if Kunz followed a local tradition that also erroneously identified St. Barbara as the protagonist of the episodes represented in the alabaster altarpiece. As an alternative, it is possible that St. Barbara was depicted as a standing figure at one of the sides of the altarpiece.

As for the information on the provenance from the church of the Madonna del Mare, this might well be referred to the polyptych of which only the Assumption of Mary survives. The church, suppressed in 1784, had three naves and three altars, the main one devoted to the Virgin. In 1655 the building was seriously damaged by a fire. Refurbished and re-consecrated in 1658, the main altar was equipped with a new painted altarpiece, while 'Above the entrance door of the church a stone low relief with the image of the Blessed Mary was placed'104, probably saved from the fire. This relief might be identified with the alabaster panel, which might have formed part of the original furnishing of the church damaged by the fire in 1655 .

Many other alabaster carvings exist and surely existed in the Italian peninsula, testifying to the high value that such artworks were credited with. The many ports Italy was provided with surely played an important role in the diffusion of English alabasters. A story that is yet to be narrated, but whose potentialities in terms of knowledge in respect to European trades, liturgical practices, artistic taste, interactions between different cultural contexts, appear to be very promising.

\footnotetext{
${ }^{100}$ C. KUNZ, Il Museo Civico di Antichità di Trieste, Trieste, 1879, p. 98.

${ }^{101}$ Cfr. F. CHEETHAM, op. cit. (n. 4), p. 91, n. 20.

${ }^{102}$ C. KUNZ, op. cit. (n. 100). On this church: V. SCUSSA, Storia cronografica di Trieste, dalla sua origine sino all'anno 1695 , con gli annali dal 1695 al 1848 , Trieste, 1863, II ed. 1968; A. TAMARO, Storia di Trieste, Rome, 1924, 2 voll., I, pp. 377-381.

${ }^{103}$ They were both imprisoned and decapitated. Cfr. Iconographie de l'Art Chrétien, III, Iconographie des Saints, I, ed. by L. Réau, Paris, 1958, pp. 169-177, 262-272.

${ }^{104}$ V. SCUSSA, op. cit. (n. 102), p. 128.
} 

VARIA 
